Yue-Xi Liu ${ }^{1,2}$, Sandra Richter ${ }^{3}$, Clemens Naumann ${ }^{3}$, Marina Braun-Unkhoff ${ }^{3}$, Zhen- $\mathrm{Yu}^{1,2}$, Combustion study of a surrogate jet fuel, Combustion and Flame, Volume 202, April 2019, pages 252-261

$<$ final revised text author version $>$

The original publication is available at www.elsevier.com https://doi.org/10.1016/j.combustflame.2019.01.022

(C) $<2019>$. This manuscript version is made available under the CC-BY-NC-ND 4.0 license http://creativecommons.org/licenses/by-nc-nd/4.0/ 


\title{
Combustion study of a surrogate jet fuel
}

\author{
Yue-Xi Liu ${ }^{1,2}$, Sandra Richter ${ }^{3}$, Clemens Naumann ${ }^{3}$, Marina Braun-Unkhoff ${ }^{3}$, Zhen-Yu Tian $^{1,2,}$ \\ ${ }^{1}$ Institute of Engineering Thermophysics, Chinese Academy of Sciences, 11 Beisihuanxi Rd., Beijing 100190, China \\ ${ }^{2}$ University of Chinese Academy of Sciences, 19A Yuquan Rd., Beijing 100049, China \\ ${ }^{3}$ Institute of Combustion Technology, German Aerospace Center (DLR), 70569 Stuttgart, Germany
}

\begin{abstract}
The oxidation of a three-component surrogate jet fuel (consisting of $n$-dodecane 66.2\%, n-propylbenzene $15.8 \%$ and 1,3,5-trimethylcyclohexane $18.0 \%$, in mol) was studied experimentally and numerically within a wide range of temperature, fuel equivalence ratio, and pressure. Three different experimental set-ups were exploited, here a jet stirred reactor (JSR), a shock tube, and a laminar burner referring to measured data of species profiles $(\varphi=2.0, T=575-1100 \mathrm{~K}, p=1 \mathrm{bar})$, ignition delay times $(\varphi=1.0, p=16$ atm, $T=700-1500 \mathrm{~K})$, and burning velocities $(T=473 \mathrm{~K}, p=$
\end{abstract} latm, $\varphi=0.6-2.0)$. Based on the experimental measurements, an updated detailed chemical-kinetic mechanism involving 401 species and 2838 reactions was developed, for a more detailed understanding of the oxidation and combustion of the surrogate fuel. In addition, quantum chemical methods have been applied for the determination of important initiation reactions by using the Gaussian and ChemRate software. In general, the predictions obtained with the mechanism developed in this work show a reasonable, often good agreement with respect to the measured mol fraction profiles (JSR), ignition delay time data (shock tube), and burning velocities data (flame). A negative temperature coefficient (NTC) behavior was observed in the JSR and shock tube experiments, due to the long-chain alkanes, here n-dodecane. The NTC effect was successfully predicted by the reaction model, with the predictions matching the measurements well. From the JSR experiments, 1-octene, 2-propenylbenzene, and propene were detected by GC and GC-MS as major intermediates within the oxidation of the surrogate. According to rate-of-production analysis

\footnotetext{
*Corresponding author, Tel/Fax: +86-10 8254 3184, E-mail: tianzhenyu@iet.cn.
} 
performed at $675 \mathrm{~K}$ and $900 \mathrm{~K}, 1,3,5$-trimethylcyclohexane (T135MCH) was found to be mainly consumed through $\mathrm{H}$-abstraction reactions and forming $\mathrm{C}_{9} \mathrm{H}_{17}$ radicals, which mostly isomerize to iso-alkane radicals and further on, decompose to light hydrocarbons. According to the comparison of predicted data on ignition (shock tube) and burning velocity (flame) with experimental ones, the selected surrogate fuel is considered to be able to reproduce the combustion behavior of a typical crude-oil stemming jet fuel. The surrogate fuel mechanism as well as the experimental data will be of significant impact on the use in the further work of the combustion of a jet fuel and of other synthetic aviation fuels as well.

Keywords: Surrogate fuel; Jet stirred reactor; Ignition delay times; Burning velocities; Modeling. 


\section{Introduction}

Aviation industry experienced a rapid growth in both civilian and military area in the past decades. The aviation fuels, as the energy source of aircrafts, have been studied with respect to high efficiency and low pollutant emissions, especially in the combustion field. Several studies indicated that alkanes, both n- and iso-alkanes, cycloalkanes, and aromatics are the major components of the aviation fuels certified [1-5]. For example, the analysis of Chinese No. 3 (RP-3) aviation kerosene using gas chromatography-mass spectrometer (GC-MS) by Zheng et al. [6] yielded 53.0\% alkanes, $37.7 \%$ cycloalkanes, $4.6 \%$ aromatics (percentage in mass), and other minor species. Also, the composition of a typical Jet-A fuel was analyzed by the same method yielding to paraffins $(60.0 \%)$, cycloalkanes $(20.0 \%)$, aromatics $(18.0 \%)$, and olefins $(2.0 \%)$ in vol\% [1, 7]. As aviation fuels typically are mixtures of up to hundreds of different hydrocarbon species, a chemical kinetic reaction model involving all these components can hardly be constructed. Thus, the strategy of surrogate mixtures composed of only a few compounds has been used to make efficient modeling feasible $[1-10]$.

In recent years, the oxidation of Jet A-1 as well as Jet A were studied by many researchers by using few-component surrogate fuels $[2,3,5,11-13]$, including flame studies, low-temperature oxidation, and high pressure combustion investigations. A few studies of RP-3 fuel were also reported including reduced combustion kinetic models [6, 14-20]. These studies were mostly focusing on high pressure experiments of jet and surrogate fuels, with scarce oxidation studies of surrogate fuels, especially with respect to the development of a detailed reaction mechanism of a specific surrogate jet fuel. As alkanes, mono- and poly-aromatics and cycloalkanes (also called naphthenes) are the three major compounds of jet fuels, the specific surrogate fuel as given by Xu et al. [20], 66.2\% n-dodecane, 15.8\% n-propylbenzene (NPB), and 18.0\% 1,3,5-trimethylcyclohexane 
(T135MCH), was used in the present work to study its detailed combustion kinetics. Although originally developed as an RP-3 surrogate, this specific surrogate mimics the composition of a Jet A fuel since the three selected initial components cover n-alkanes (n-dodecane), aromatics (NPB), and branched cycloalkanes $(\mathrm{T} 135 \mathrm{MCH})$; moreover, several iso-alkanes will be generated by the isomerization of $\mathrm{T} 135 \mathrm{MCH}$ during the combustion process. Furthermore, the composition of this surrogate is similar to the above mentioned Jet A fuel analysis. Its $\mathrm{H} / \mathrm{C}$ ratio of 2.03 and mol weight of $148 \mathrm{~g} \mathrm{~mol}^{-1}$, respectively, match the corresponding values of Jet A-1 (1.91 and $153 \mathrm{~g} \mathrm{~mol}^{-1}$ [1]) as well as of RP-3 (2.05 and $150 \mathrm{~g} \mathrm{~mol}^{-1}$ [20]). Therefore, this surrogate is appropriate to represent a RP-3 and a Jet A-1 fuel. Hence, it is justified to use the surrogate within the experiments for comparison with Jet A-1 and the developed reaction mechanism of this surrogate should be suitable to predict the combustion behavior of Jet A-1 as well.

Concerning about previous kinetic work of the specific components of the surrogate, almost no kinetic study on TMCH oxidation was reported, in contrast to n-dodecane and NPB, with many studies available. In the last years, n-dodecane pyrolysis and oxidation was studied in detail [21-27] with providing also information on a kinetic model; furthermore, a few theoretical studies [28-31] were also published. At the same time, NPB was widely investigated in low pressure flame [32], auto-ignition [33-35], pyrolysis [36], and oxidation [37, 38] experiments.

These studies were mostly focusing on high pressure experiments of jet and surrogate fuels, with scarce oxidation studies of surrogate fuels, especially with respect to the development of a detailed reaction mechanism of a specific surrogate jet fuel.

The present work aims to study the low-temperature oxidation as well as two fundamental combustion properties of a three-component surrogate jet fuel (66.2\% n-dodecane, $15.8 \%$ NPB, and $18.0 \% \mathrm{~T} 135 \mathrm{MCH}$ by mol) by providing data on species profiles, ignition delay times, and laminar 
burning velocities within a relevant range of temperature, pressure, and fuel equivalence ratio. Based on the experimental measurements, a comprehensive reaction model was developed, with exploiting quantum chemical methods for the calculations of rate coefficient parameters of $\mathrm{H}$-abstraction reactions of the surrogate components. Rate-of-production (ROP) and sensitivity analyses were performed to identify the major consumption channels of the surrogate. The detailed reaction mechanism with 401 species and 2838 reactions will improve the understanding of the combustion characteristics of the surrogate fuel; the reaction model developed within the present work is included within the Supplements.

\section{Experiments}

\section{Mol fraction profiles}

The experiments were performed in a jet stirred reactor (JSR) used recently in our previous work [38-40] at ambient pressure $(p=1 \mathrm{~atm})$ and temperatures ranging between 575 and $1100 \mathrm{~K}$. The inlet concentration of the surrogate fuel was chosen to $0.5 \%$ (gas phase) diluted with argon, at a fuel equivalence ratio $(\varphi)$ of 2.0. The equivalence ratio of 2.0 will favor the formation of aromatic species (a major soot precursor) considerably; thus, these species can be easier detected by GC and GC-MS; and the information on the intermediates pattern is of benefit for the validation and improvement of the mechanism. In contrast, the oxidation of any fuel at equivalence ratios of $\varphi=1.0$ and/or $\varphi=0.4$ would generate less intermediates with less concentration and/or rapid generation and consumption. For these reasons, the experiments were decided to be performed under a very fuel-rich condition, at an equivalence ratio of $\varphi=2.0$. A more detailed description could be found in the Supplemental Material. Mass flow controllers (MKS) allow to control the flow rates of $\mathrm{O}_{2}(4.1 \%$, $99.9999 \%$ purity by volume) and $\operatorname{Ar}(95.4 \%, 99.9999 \%$ purity by volume). The specific purity of the 
three components are: n-dodecane (98\%, Aladdin), NPB (>99\%, TCI, Japan), and T135MCH (>98\%, TCI, Japan). The fuel itself was injected by a high-pressure infusion pump (FL2200, Zhejiang Fuli Analytical Instrument Co., Ltd., China) and vaporized at $473 \mathrm{~K}$ in a vaporization tank. All tubes were preheated to $T=503 \mathrm{~K}$ to avoid condensation. A K-type thermocouple located at the center of the sphere was used to measure the reaction temperature. Online GC and GC-MS (Agilent 7890B, America) were exploited to analyze 25 stable species in total, with $\mathrm{CO}, \mathrm{CO}_{2}, \mathrm{H}_{2}$, alkanes, aromatics, and oxidized hydrocarbons among them. The composition of test gas mixture is shown in Table 1. The original experimental results and detailed information about the analyzing methods are available in Section 1 in the Supplemental Material (SM).

Table 1 Composition of the fuel mixture as used within the low temperature oxidation of the surrogate in the JSR ( $\mathrm{mol} \%)$

\begin{tabular}{cccccc}
\hline$\varphi$ & N-dodecane & T135MCH & NPB & $\mathrm{O}_{2}$ & $\mathrm{Ar}$ \\
\hline 2.0 & $0.331 \%$ & $0.090 \%$ & $0.079 \%$ & $4.140 \%$ & $95.360 \%$ \\
\hline
\end{tabular}

Note: The total volume and mass flow rate of surrogate fuel are $1000.00 \mathrm{sccm}$ and $0.047 \mathrm{ml} \mathrm{min}{ }^{-1}$, respectively.

\section{Ignition delay time}

Ignition delay times were measured in a high pressure shock tube (46 $\mathrm{mm}$ internal diameter), with a $10 \mathrm{~m}$ driver section and a $3.25 \mathrm{~m}$ driven section, at pressures behind reflected shock waves of about $p=16$ bar and for stoichiometric fuel air mixtures. Since the experimental approach has been already discussed in detail in previous studies (e.g. $[2,41,42])$ only a short description is given here. The driven section was electrically heated to $T=433 \mathrm{~K}$, the driver section to $T=393 \mathrm{~K}$. He-Ar mixtures were used as driver gas to achieve tailored interface conditions [43]. Test gas mixtures were prepared for each experiment by injecting the liquid fuel with a syringe onto fibers permanently 
purged by hot nitrogen which evaporated and transported the fuel into an evacuated mixing vessel. Preheated nitrogen and synthetic air were added thereafter to adjust the specific $\varphi$-value, here, $\varphi=$ 1.0, and the selected dilution, respectively, here 1:2 in nitrogen. The incident shock speed was measured over three $30 \mathrm{~mm}$ intervals using four piezo-electric pressure transducers. The initial temperature and pressure behind the reflected shock wave were computed from the measured incident shock speed and the attenuation using a one-dimensional shock model [44].

\section{Laminar burning velocity}

Values of the laminar burning velocity $\left(S_{\mathrm{u}}\right)$ were determined within a wide $\varphi$-range at a preheat temperature of $T=473 \mathrm{~K}$ at pressures of $p=1$ bar by applying the cone angle method. According to Eq. (1):

$$
S_{\mathrm{u}}=v_{\mathrm{u}} \cdot \sin \alpha
$$

$S_{\mathrm{u}}$-values are calculated from the cone angle $(\alpha)$ of the flame and the gas velocity $\left(v_{\mathrm{u}}\right)$ of the unburned fuel-air mixture $[45,46]$. The preheat temperature of $473 \mathrm{~K}$ was chosen as set temperature for the measurement to ensure vaporization and to avoid both condensation and autoignition of the vaporized fuel in the test rig. This is in particular needed for a complex multi-component mixture typical for a jet fuel, having also a broad boiling range. 


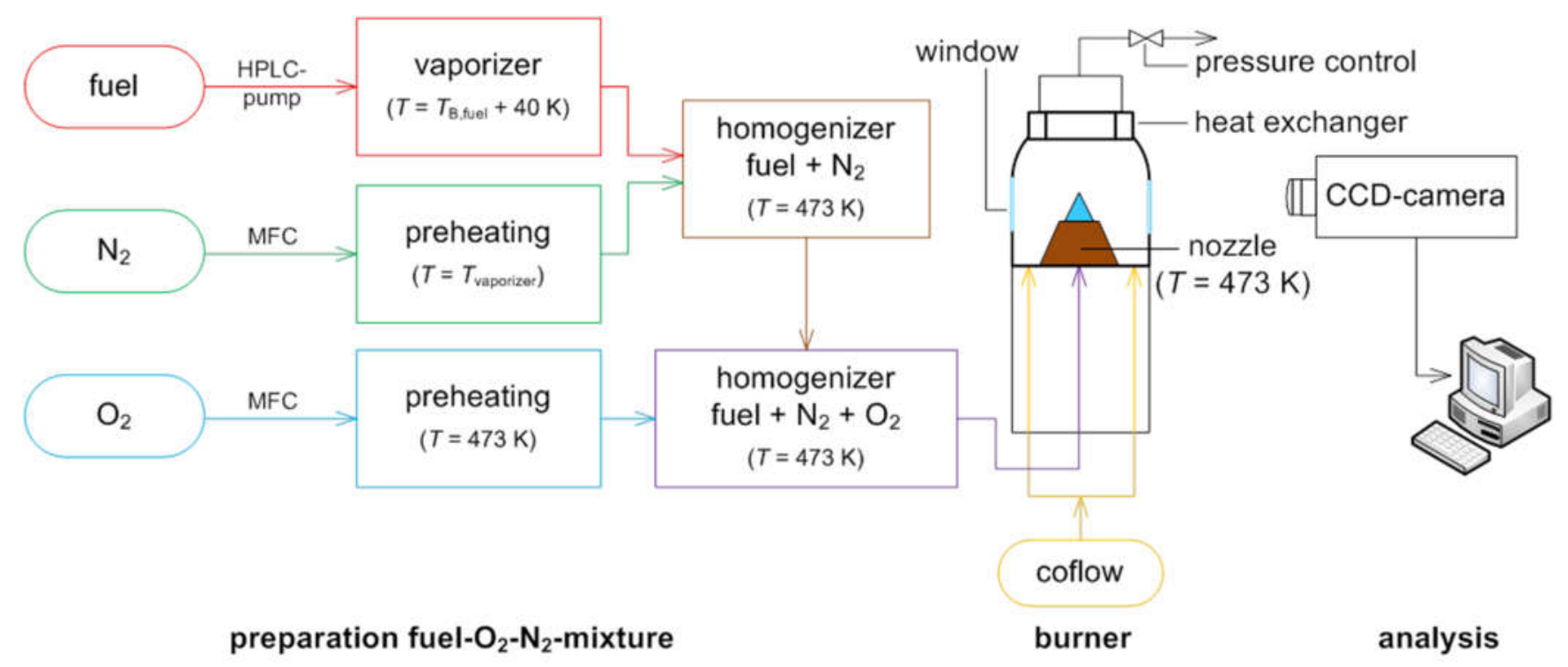

Fig. 1 Experimental set-up for the measurements of the laminar burning velocity (MFC - mass flow controller, $T_{\mathrm{B}}$ - boiling temperature)

For the determination of the cone angle, premixed conical-shaped flames have been stabilized above a flame holder by the use of a coflow, either air for rich flames $(\varphi \geq 1.0)$ or a mixture of $5 \%$ $\mathrm{CH}_{4}+5 \% \mathrm{H}_{2}+90 \% \mathrm{~N}_{2}$ for lean flames $(\varphi \leq 1.0)$. A scheme of the experimental set-up is shown in Fig. 1. For the preparation of the fuel-air mixture, the fuel was first vaporized at temperatures at about $523 \mathrm{~K}$, then mixed with a preheated $\mathrm{N}_{2}$-stream (Linde, 99.999\%), and adjusted to the setting temperature of $T=473 \mathrm{~K}$. In a second homogenizing step, molecular oxygen (Linde, 99.95\%) was added according to the ratio in air $\left(\mathrm{N}_{2}: \mathrm{O}_{2}=0.79: 0.21\right)$. The cone angle detection was performed by recording pictures with a CCD-camera (Imager Intense, LaVision). The used burner set-up has been described in previous studies, e.g. [42, 47], where more details of the experiment are given.

\section{Modeling}

The PSR code and the adapted SENKIN code of the CHEMKIN-II software package were used to simulate the JSR data and ignition delay times [44], respectively. In the present work, the ignition 
delay time is defined as the time between the initiation of the reactive system by the reflected shock wave and the occurrence of the $\mathrm{CH}^{*}$-maximum, with the same definition used for the calculations, too. Simulations of the laminar burning velocities were performed with the open-source software Cantera [48] using the free flame model and by considering the multi-component diffusion model and thermo-diffusion. The used transport data were based on the Chemkin Transport Database [49]. Mesh points were refined to achieve equal solution tolerance leading to about 120 mesh points.

The low-temperature reaction mechanism as used in the present work is based on our recent mechanism which has been developed for describing the oxidation behavior of NPB [38]. The sub model of n-dodecane oxidation was employed from Banerjee's model [21]. This one leads to a better agreement with measured species profiles compared to predictions using the very comprehensive sub model of n-dodecane as presented by Mzé-Ahmed et al. [25]. Comparison results are given exemplarily for n-dodecane, T135MCH, NPB, $\mathrm{CO}, \mathrm{CO}_{2}$, and $\mathrm{H}_{2}$ in the Supplemental Material. The sub model of T135MCH was constructed based on the reaction model of methylcyclohexane (MCH) as given by Wang et al. [50]). The low temperature mechanism was also considered and estimated by refering to the low temperature mechanisms of cyclohexane and ethylcyclohexane as reported by Mzé-Ahmed et al. [25] and Ning et al. [51], respectively. The rate coefficients of three H-abstraction reactions of $\mathrm{T} 135 \mathrm{MCH}$ were updated: First, the structure and the energy of the transient states were calculated by exploiting the Gaussian 16 software [52] at the CBS-QB3 level [53]; then, the rate constants were updated based on the results as calculated applying the ChemRate software [54]. The calculated results are shown in Figure S1 (see Section 3 of the SM). The reactions of the T135MCH subset, in total 109 reactions with 30 species involved, are collected in Table S2 (see SM).

The coupled reactions between the three surrogate components, with 39 reactions involved, were elaborated within the present work. Six radical isomers of n-dodecane, namely $\mathrm{PXC}_{12} \mathrm{H}_{25}$, 
$\mathrm{SXC}_{12} \mathrm{H}_{25}, \mathrm{~S} 2 \mathrm{XC}_{12} \mathrm{H}_{25}, \mathrm{~S} 3 \mathrm{XC}_{12} \mathrm{H}_{25}, \mathrm{~S} 4 \mathrm{XC}_{12} \mathrm{H}_{25}$, and $\mathrm{S} \mathrm{XC}_{12} \mathrm{H}_{25}$, three radical isomers of NPB,

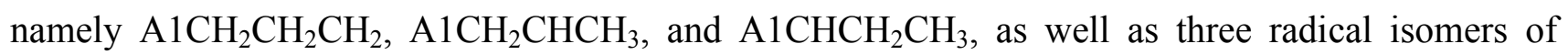
T135MCH, namely $\mathrm{PXCH}_{2} \mathrm{D} 35 \mathrm{MCH}$, TXT135MCH, and $\mathrm{SXD} 35 \mathrm{MCH}$, were integrated into the coupled reaction network mechanism. The thermochemical data of the species involved in the reactions of the T135MCH subset were calculated by using THERGAS [55]. These species as well as their corresponding structures and thermochemical data are listed in Table S3 in Section 4 of the SM. The complete reaction mechanism composed of 401 species and 2838 reactions as well as the thermochemical and transport data are available within SM.

\section{Results and discussion}

\subsection{ROP and sensitivity analysis}

To illustrate the major reaction channels of surrogate compounds, a reaction flux analysis has been performed at $T=900 \mathrm{~K}$, at a conversion ratio of $60.3 \%$ for $\mathrm{T} 135 \mathrm{MCH}, 42.1 \%$ for $\mathrm{NPB}$, and $62.3 \%$ for n-dodecane, respectively. The low temperature part was also considered at $T=675 \mathrm{~K}$, to account for the NTC regime. At these two temperatures, as presented in Fig. 2, the major consumption pathway of $\mathrm{T} 135 \mathrm{MCH}$ is the $\mathrm{H}$-abstraction from the ring, to produce $\mathrm{SXD} 35 \mathrm{MCH}$ (64.05\% and $75.46 \%$ ), which could isomerize to $\mathrm{PXCH}_{2} \mathrm{D} 35 \mathrm{MCH}$ at low temperature $(27.97 \%)$. Over $90 \%$ of the $\mathrm{H}$-abstraction reaction occurred with $\mathrm{OH}$ radicals. At high temperature, the three $\mathrm{C}_{9} \mathrm{H}_{17}$ radicals ( $\mathrm{PXCH}_{2} \mathrm{D} 35 \mathrm{MCH}, \mathrm{SXT135MCH}$, and TXT135MCH, seen in Fig. 2) mainly tend to isomerize to open-chain $\mathrm{C}_{9} \mathrm{H}_{17}$ hydrocarbon radicals and decompose by $\mathrm{C}-\mathrm{C}$ bond breaking to $\mathrm{C}_{3} \mathrm{H}_{6}$. The minor consumption pathways of $\mathrm{C}_{9} \mathrm{H}_{17}$ radicals are the abstraction reactions to form the benzene ring system, and thus, leading to the formation of benzene, toluene, and 1,3,5-trimethylbenzene (T135MB), respectively. These consumption channels are similar to the ones observed within the 
oxidation of methylcyclohexane [50]; methylcyclohexane is mostly consumed through $\mathrm{H}$-abstraction reactions, followed by the isomerization of the formed radicals to linear $\mathrm{C}_{6}$ or $\mathrm{C}_{7}$ hydrocarbons, and finally, by their decomposition to linear hydrocarbons. Meanwhile, the $\mathrm{MCH}$ radicals continue to be consumed through $\mathrm{H}$-abstraction reactions and finally formed benzene or toluene, as the minor pathways.

However, at $T=675 \mathrm{~K}$, the pathways of $\mathrm{C}_{9} \mathrm{H}_{17}$ radicals significantly changed. At this lower temperature, $\mathrm{C}_{9} \mathrm{H}_{17}$ radicals are rarely consumed through ring-opening reactions; instead, $\mathrm{C}_{9} \mathrm{H}_{17}$ radicals are mostly consumed through $\mathrm{H}$-abstraction reactions $\left(\mathrm{PXCH}_{2} \mathrm{D} 35 \mathrm{MCH}\right)$, methyl-abstraction reactions $(\mathrm{SXD} 35 \mathrm{MCH})$, and $\mathrm{H}$-addition reactions (TXT135MCH, back to $\mathrm{T} 135 \mathrm{MCH})$.

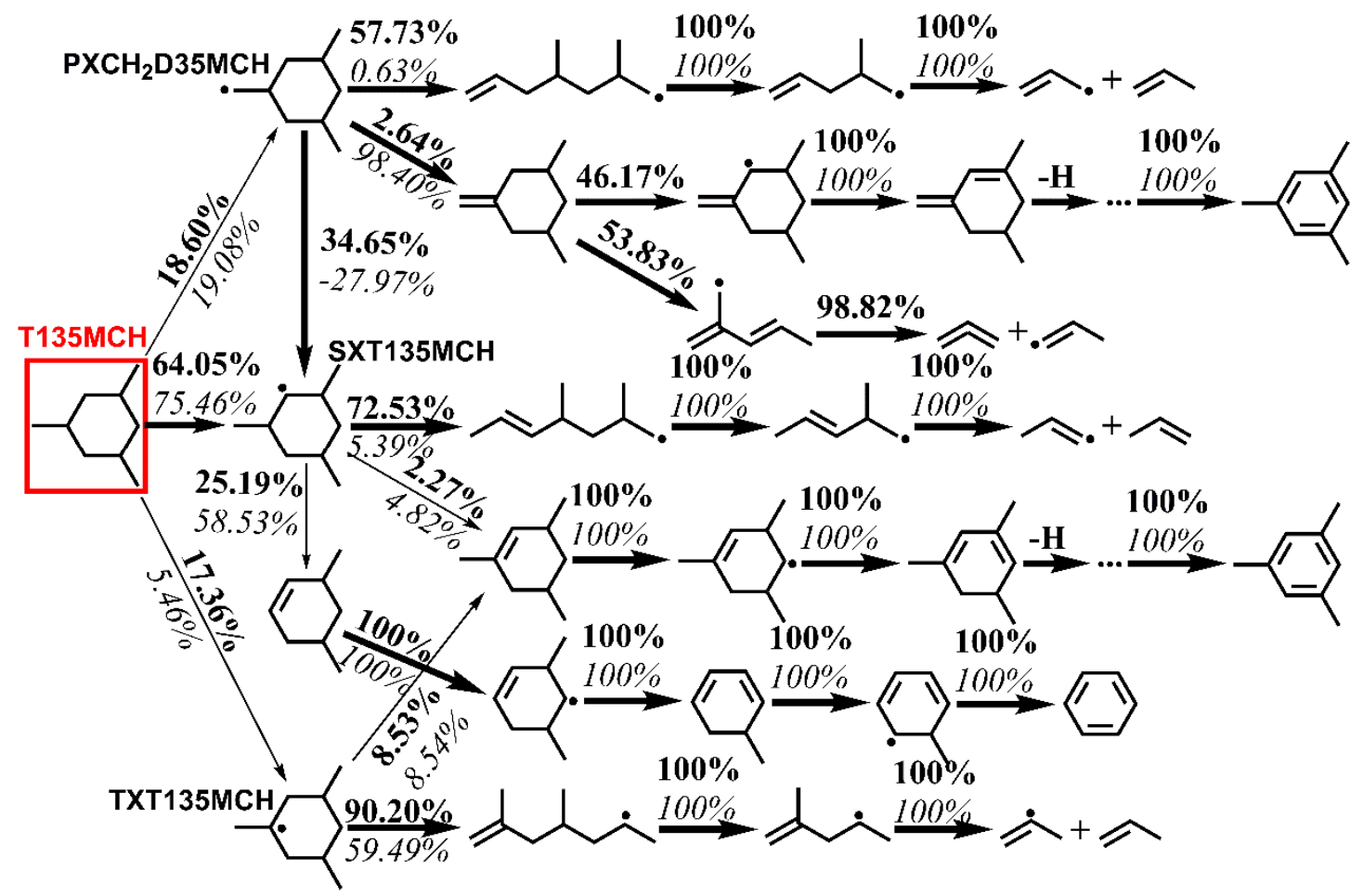

Fig. 2 ROP analysis of low-temperature oxidation of 1,3,5 trimethylcyclohexane (T135MCH) at $T=$ $900 \mathrm{~K}(60.3 \%$ conversion, bold $)$ and $675 \mathrm{~K}(62.5 \%$ conversion italic $), p=1$ atm and $\varphi=2.0$.

Figure 3 shows the major consumption pathways of $\mathrm{AlC}_{3} \mathrm{H}_{7}(\mathrm{NPB})$ at $675 \mathrm{~K}$ and $900 \mathrm{~K}$. It is 
found that the fuel's initial consumption is hardly influenced by temperature in contrast to the secondary pathways. There are more reactions which force the radicals going back to bigger molecules and generate NPB at $675 \mathrm{~K}$ finally. This explains the unapparent NTC region of NPB; n-propylbenzene (NPB) is primarily converted to $\mathrm{A}_{1} \mathrm{CHCH}_{2} \mathrm{CH}_{3}(35.06 \%)$ and $\mathrm{A}_{1} \mathrm{CH}_{2} \mathrm{CHCH}_{3}$

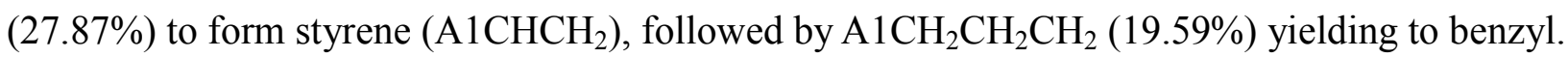

Moreover, another pathway of NPB decomposing to benzene and n-propyl, which is not shown in Fig. 3, contributes to about 10\% consumption of NPB. It maintains the same pathway as observed within the oxidation of pure NPB only [38]. Thus, NPB exhibits to be the main precursor of aromatic intermediates within the RP-3/Jet A-1 surrogate oxidation, with styrene identified as the major intermediate, besides benzene and toluene, within NPB oxidation. Similar to the pure NPB oxidation, more $\mathrm{A}_{1 \mathrm{CH}_{2}} \mathrm{CHCH}_{3}$ is consumed through isomerization reaction because this isomerization reaction has less energy barrier $(7780 \mathrm{cal} / \mathrm{mol})$ than the ones of the other corresponding reactions (around $10000 \mathrm{cal} / \mathrm{mol}$ ), with no need of any further radical to be involved. Keep in mind that within the oxidation of T135MCH, pathways forming T135MB are only of minor importance.

Since the combustion of n-dodecane has been discussed in detail previously [21], the main features of the ROP and sensitivity analysis of n-dodecane will be introduced briefly. N-dodecane is mostly consumed through $\mathrm{H}$-abstraction reactions yielding six possible $\mathrm{C}_{12} \mathrm{H}_{25}$ radicals. These radicals tend to form a peroxide radical $\left(\mathrm{PC}_{12} \mathrm{H}_{25} \mathrm{O}_{2}\right)$ by $\mathrm{O}_{2}$ addition at low temperature; $\mathrm{PC}_{12} \mathrm{H}_{25} \mathrm{O}_{2}$ isomerizes and decomposes to $\mathrm{C}_{10} \mathrm{H}_{21}$ along with $\mathrm{OH}, \mathrm{CO}$, and $\mathrm{CH}_{2} \mathrm{O}$. The radical $\mathrm{C}_{10} \mathrm{H}_{21}$ will further decompose to $\mathrm{C} 9$ to $\mathrm{C} 2$ hydrocarbon species by $\mathrm{C}-\mathrm{C}$ bond breaking. At high temperatures (above $1000 \mathrm{~K}$ ), the main pathway is the direct decomposition of $\mathrm{C}_{12} \mathrm{H}_{25}$ to smaller hydrocarbon species. 


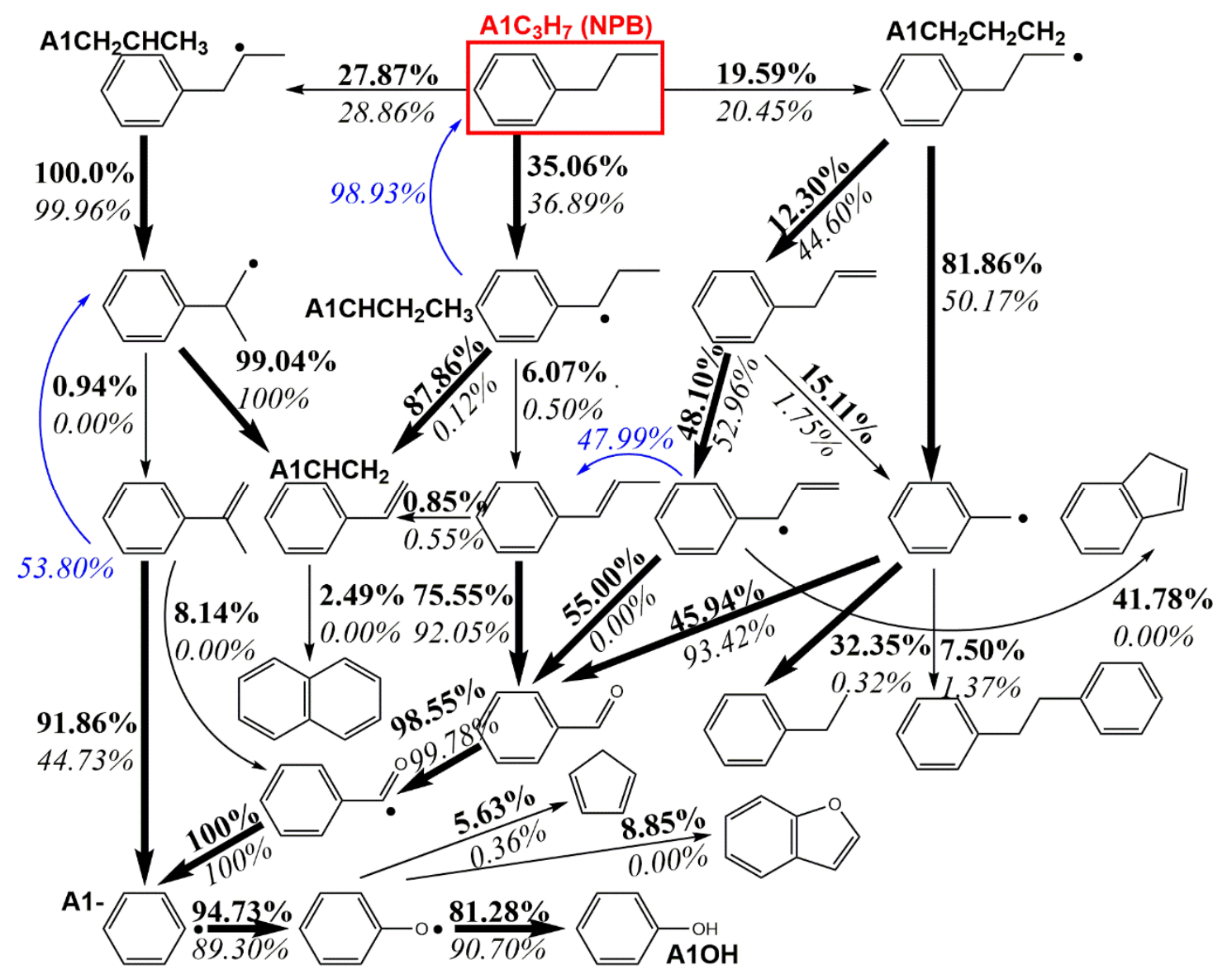

Fig. 3 ROP analysis of low-temperature oxidation of n-propylbenzene (NPB) at $T=900 \mathrm{~K}(42.1 \%$ conversion, bold) and $675 \mathrm{~K}(23.9 \%$ conversion italic), $p=1$ atm, $\varphi=2.0$. Blue arrow indicates the pathway only dominates at $675 \mathrm{~K}$.

To identify the reactions that serve as key pathways in the consumption of T135MCH and NPB, a local sensitivity analysis (SA) has been performed for the present model, as shown in Fig. 4. It is interesting to find that no initial reactions exhibit a significant promoting effect for $\mathrm{T} 135 \mathrm{MCH}$ consumption; only the reaction $\mathrm{A}_{1} \mathrm{C}_{3} \mathrm{H}_{7}+\mathrm{OH}=\mathrm{A} 1 \mathrm{CH}_{2} \mathrm{CH}_{2} \mathrm{CH}_{2}+\mathrm{H}_{2} \mathrm{O}$ plays an important role in the NPB consumption sensitivity analysis due to the dominating effect by n-dodecane in the surrogate consumption. As shown in Fig. 4, sensitivity analysis reveals also that $\mathrm{CH}_{3}+\mathrm{O}_{2}=\mathrm{CH}_{2} \mathrm{O}+\mathrm{OH}$ and $\mathrm{CH}_{3}+\mathrm{CH}_{3}(+\mathrm{M})=\mathrm{C}_{2} \mathrm{H}_{6}(+\mathrm{M})$ are the most promoting and inhibiting reactions, respectively, for both fuels, at $900 \mathrm{~K}$. This means that the methyl radical $\left(\mathrm{CH}_{3}\right)$ is the key intermediate in the NPB and T135MCH consumption network at $900 \mathrm{~K}$. The oxidation of n-dodecane consumes more $\mathrm{H} / \mathrm{OH} / \mathrm{HO}_{2}$ 
radicals and leads to inhibition effects (rate retarding) on the oxidation of NPB and T135MCH at high temperatures. Thus, it will promote NPB and T135MB consumption at low temperatures as it is the initial reaction of surrogate consumption. The reactions $\mathrm{P} 12 \mathrm{OOHX} 2=\mathrm{PC}_{12} \mathrm{H}_{25} \mathrm{O}_{2}$ and $\mathrm{P} 12 \mathrm{OOHX} 2+\mathrm{O}_{2}=\mathrm{SOO} 12 \mathrm{OOH}$ promote and inhibit both fuel consumptions, especially at low temperature, since these two reactions lead to two directions in the n-dodecane consumption network (back to $\mathrm{PC}_{12} \mathrm{H}_{25} \mathrm{O}_{2}$ and yield to $\mathrm{SOO} 12 \mathrm{OOH}$, respectively). It is interesting to find that the initial reaction of NPB $\left(\mathrm{AlC}_{3} \mathrm{H}_{7}+\mathrm{OH}=\mathrm{A} 1 \mathrm{CHCH}_{2} \mathrm{CH}_{3}+\mathrm{H}_{2} \mathrm{O}\right)$ plays different roles in NPB and TMCH oxidations at $900 \mathrm{~K}$. This phenomenon is mainly caused by the competition on $\mathrm{H} / \mathrm{OH} / \mathrm{O} / \mathrm{HO}_{2}$ radicals between NPB and T135MCH, two of the three components of the specific surrogate as selected within this work.

As $n$-dodecane is the major compound in this specific surrogate $(66.2 \%$ in mol), its oxidation needs much more radicals compared to the oxidation of NPB and T135MCH, respectively. Thus, with less oxygen available at fuel rich conditions, less radicals are available for the oxidation of T135MCH or NPB. As a result, the consumption of one compound (NPB) will exhibit a negative effect on the sensitivity analysis of the other compound (T135MCH). At $675 \mathrm{~K}$, the reactions belong to the n-dodecane low temperature mechanism dominating the promoting effect in NPB and T135MCH consumption. Therefore, at low temperature, n-dodecane is the most active component and is able to initiate the oxidation of the surrogate. The consumptions of the other two surrogate components are driven by the initiation of n-dodecane. 

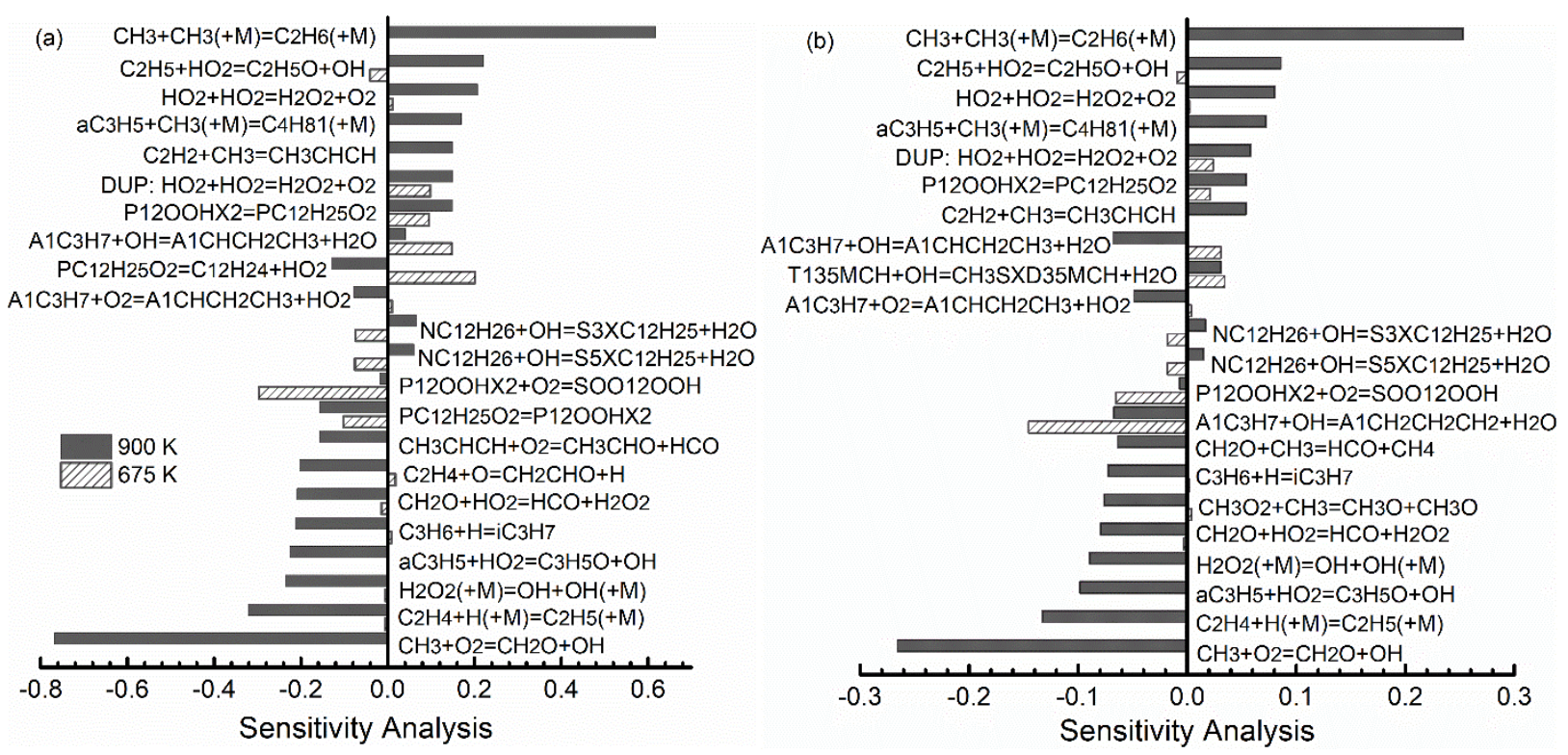

Fig. 4 Sensitivity analysis of the surrogate oxidation at low temperatures focusing on $\mathrm{T} 135 \mathrm{MCH}$ (a) and NPB (b) at 900 and $675 \mathrm{~K}, 1 \mathrm{~atm}, \varphi=2.0$. The temperature of $900 \mathrm{~K}$ corresponds to $60.3 \%$ conversion for $\mathrm{T} 135 \mathrm{MCH}$ and $42.1 \%$ for $\mathrm{NPB}$, respectively. The temperature of $675 \mathrm{~K}$ corresponds to $62.5 \%$ conversion for $\mathrm{T} 135 \mathrm{MCH}$ and $23.9 \%$ for NPB, respectively.

\subsection{Mol fraction profiles}

In the current work, 25 different species were detected; their mol fraction profiles will be shown to be predicted reasonable, often well, by the reaction model as developed within the present work. Considering the objective of the surrogate application, only the reactants, products, and six major intermediates are discussed in detail in this part; further mol fraction profiles are available in Section 5 of the SM. Strong effects of the negative temperature coefficient (NTC) on the oxidation of NPB and $\mathrm{T} 135 \mathrm{MCH}$ were observed in the present work.

Figure 5 shows the mol fraction profiles of n-dodecane, T135MCH, and NPB (surrogate fuel components) as well as $\mathrm{CO}, \mathrm{CO}_{2}$, and $\mathrm{H}_{2}$. In general, the current model predicts the conversion of the surrogate components and the generation of the three major products well. The oxidation of the surrogate fuel starts at $600 \mathrm{~K}$. All components show a NTC effect almost back to initial state at $775 \mathrm{~K}$. Then the compounds start to be consumed again at $800 \mathrm{~K}$, and are fully converted at $1000 \mathrm{~K}$. 
This NTC effect was already observed in the previous study of n-dodecane [25].

According to the ROP study, T135MCH is mainly consumed with the help of $\mathrm{H}$ and $\mathrm{O}_{2}$, similar to n-dodecane, leading to the NTC effect between these initial reactions of the two components. So it can be estimated that a distinct NTC effect occurs in the oxidation of pure $\mathrm{T} 135 \mathrm{MCH}$, similar to n-dodecane. Actually, the mol fraction curve of NPB within pure NPB oxidation did not exhibit a NTC region. But in this surrogate experiment, NPB, in combination with the other compounds, shows a NTC effect, obviously. When n-dodecane and T135MCH are consumed within the NTC region, large amounts of $\mathrm{OH}$ and $\mathrm{HO}_{2}$ radicals are released via the $\mathrm{H}$-abstractions reactions. These radicals will react with NPB yielding $\mathrm{A}_{1} \mathrm{C}_{3} \mathrm{H}_{6}$ radicals, and, thus, finally will result in the obvious consumption at low temperatures. $\mathrm{CO}$ as a major product is slightly underpredicted at high temperatures. The peroxide $\mathrm{OC}_{12} \mathrm{OOH}$ is the major precursor of the $\mathrm{CO}$ production path at low temperatures, whereas the pathway: $\mathrm{HCO}+\mathrm{O}_{2}=\mathrm{CO}+\mathrm{HO}_{2}$ is the main production way of $\mathrm{CO}$ at high temperatures.

According to the results of the ROP analysis, $\mathrm{OC}_{12} \mathrm{OOH}$ was formed from $\mathrm{C}_{12} \mathrm{H}_{25}$ radicals, which were generated from the reactions with negative temperature coefficient (here, negative " $n$ " in the Arrhenius equation). As the temperature is increasing, less $\mathrm{C}_{12} \mathrm{H}_{25}$ radicals are consumed through $\mathrm{OC}_{12} \mathrm{OOH}$ leading to a lower $\mathrm{CO}$ production. $\mathrm{CO}_{2}$ is also slightly underpredicted, especially at the NTC region, mainly because the key reaction of $\mathrm{CO}_{2}$ formation at low temperatures is: $\mathrm{CO}+\mathrm{OH}=\mathrm{CO}_{2}+\mathrm{H}$, with a low reaction rate at $675 \mathrm{~K}$. The low mol fraction of $\mathrm{C}_{2} \mathrm{H}_{3} \mathrm{CHO}$ also contributes to the under prediction of $\mathrm{CO}_{2}$ according to the additional $\mathrm{CO}_{2}$ formation pathway: $\mathrm{OH}+$ $\mathrm{C}_{2} \mathrm{H}_{3} \mathrm{CHO}=\mathrm{CO}_{2}+\mathrm{C}_{2} \mathrm{H}_{4}+\mathrm{H}$. This phenomenon was also seen within the n-dodecane oxidation study [25]: the prediction of $\mathrm{CO}_{2}$, which was obviously detected in the NTC region, cannot match the measured data. Hydrogen $\left(\mathrm{H}_{2}\right)$ started to be detected at $975 \mathrm{~K}$; its concentration profile is reasonably 
predicted. This confirms that $\mathrm{H}$-abstraction reactions occurring via $\mathrm{H}$ atoms are not the main pathway in the NTC region as there was hardly any molecular hydrogen detected in NTC region. In summary, the present model provides reasonable predictions on the major species at the investigated experimental conditions.
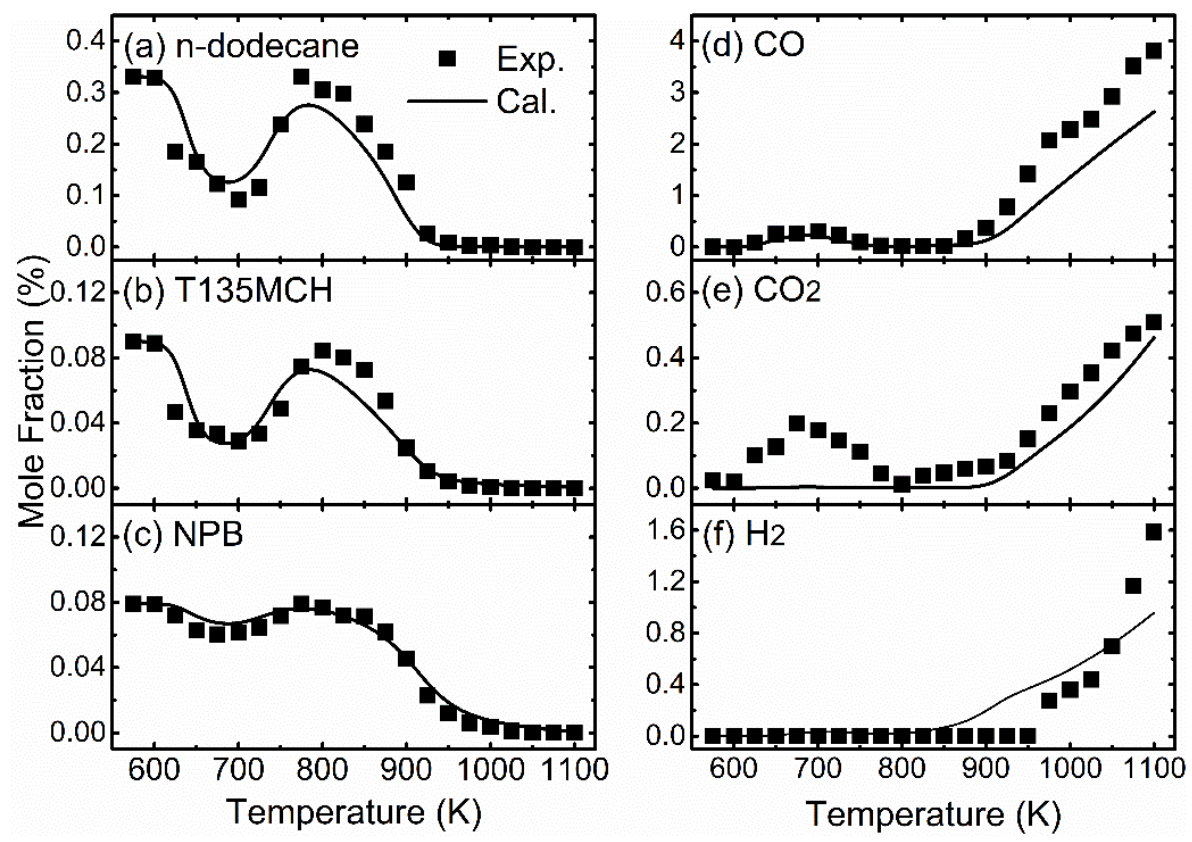

Fig. 5 Comparison between the measured (symbols) and modeling results (lines) of n-dodecane (a), T135MCH (b), NPB (c), $\mathrm{CO}$ (d), $\mathrm{CO}_{2}$ (e), and $\mathrm{H}_{2}$ (f) using the reaction model of the present work, at $p=1 \mathrm{~atm}$ and $\varphi=2.0$.

Figure 6 depicts the experimental and modeling results of six intermediates, which play a significant role in the oxidation of the three surrogate components. In general, the simulated results reproduce the experimental data well with respect to the tendencies, peak temperatures as well as most of the peak values. Methane $\left(\mathrm{CH}_{4}\right)$ as one of the most important intermediates within the oxidation of many hydrocarbons depicts a very good prediction, with the small peak in the NTC effect region also well predicted. ROP analysis reveals that $\mathrm{CH}_{4}$ is mainly produced by methyl abstraction from $\mathrm{SXD} 35 \mathrm{MCH}$ at $675 \mathrm{~K}$, resulting via $\mathrm{H}$-abstraction from $\mathrm{T} 135 \mathrm{MCH}$, not strongly 
affected by NTC behavior. At high temperatures, $\mathrm{CH}_{4}$ is stemming from the decomposition of $\mathrm{C}_{2}$ or $\mathrm{C}_{3}$ hydrocarbon radicals, respectively. The predicted profile of ethene $\left(\mathrm{C}_{2} \mathrm{H}_{4}\right)$ matches the measured data, with a slight overprediction at high temperatures. Ethene is a significant intermediate of n-dodecane because its precursor is $\mathrm{pC}_{4} \mathrm{H}_{9}$, which mainly results from the decomposition of $\mathrm{C}_{12} \mathrm{H}_{25}$ radicals, both at low and high temperatures. Propene $\left(\mathrm{C}_{3} \mathrm{H}_{6}\right)$ is also predicted well by the model of the present work. Besides $\mathrm{C}_{12} \mathrm{H}_{25}$ or $\mathrm{C}_{10} \mathrm{H}_{21}$ radicals, there are some further important $\mathrm{C}_{3} \mathrm{H}_{6}$ precursors such as $\mathrm{CH}_{2} \mathrm{D} 35 \mathrm{MCH}$ or $\mathrm{S}_{\mathrm{XC}} \mathrm{XH}_{11}-2-46 \mathrm{M}$ coming from $\mathrm{T} 135 \mathrm{MCH}$. Thus, it is assumed that the production of $\mathrm{C}_{3} \mathrm{H}_{6}$ is highly relevant within the consumption of n-dodecane and $\mathrm{T} 135 \mathrm{MCH}$. The decomposition of $n$-dodecane produces another important intermediate: $n$-butene $\left(n-C_{4} H_{8}\right)$. The present model gives a reasonable prediction against experimental data of $n-C_{4} \mathrm{H}_{8}$.

According to the ROP analysis performed, $n-\mathrm{C}_{4} \mathrm{H}_{8}$ mainly results from the decomposition of $\mathrm{S} 2 \mathrm{XC}_{12} \mathrm{H}_{25}$, by C-C bond breaking. N-Octene $\left(\mathrm{n}-\mathrm{C}_{8} \mathrm{H}_{16}\right)$ is also identified as a key species within the consumption channels of $\mathrm{n}$-dodecane. The ROP analysis reveals that there were formed several $\mathrm{C}_{5}$ to $\mathrm{C}_{11}$ alkenes during n-dodecane decomposition; however, only $n-\mathrm{C}_{7} \mathrm{H}_{14}$ (see Fig. S2, SM) and n- $\mathrm{C}_{8} \mathrm{H}_{16}$ have been identified by GC-MS, which maintained similar peak values and tendencies for both simulated and experimental data. Similar to $n-\mathrm{C}_{4} \mathrm{H}_{8}, n-\mathrm{C}_{8} \mathrm{H}_{16}$ is also generated by $\mathrm{C}-\mathrm{C}$ bond breaking of the $\mathrm{C}_{12} \mathrm{H}_{25}$ radical $\left(\mathrm{S}_{5 X C} \mathrm{XC}_{25}\right)$. Within the consumption of $\mathrm{NPB}, \mathrm{A} 1 \mathrm{CH}_{2} \mathrm{CHCH}_{2}$ is revealed as an important intermediate. As the initial concentration of NPB is quite low, the peak value of $\mathrm{A}_{1 \mathrm{CH}_{2}} \mathrm{CHCH}_{2}$ is not larger than about $50 \mathrm{ppm}$. The significant feature of the mol fraction profile of

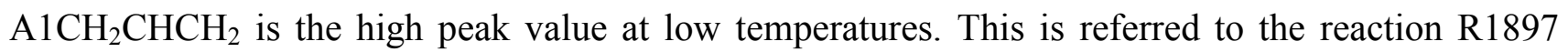

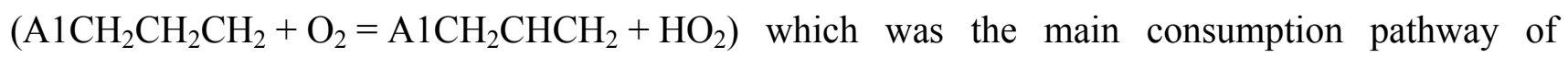
$\mathrm{A} 1 \mathrm{CH}_{2} \mathrm{CH}_{2} \mathrm{CH}_{2}$, with keeping a high reaction rate at low temperatures and becoming less active at high temperatures. 

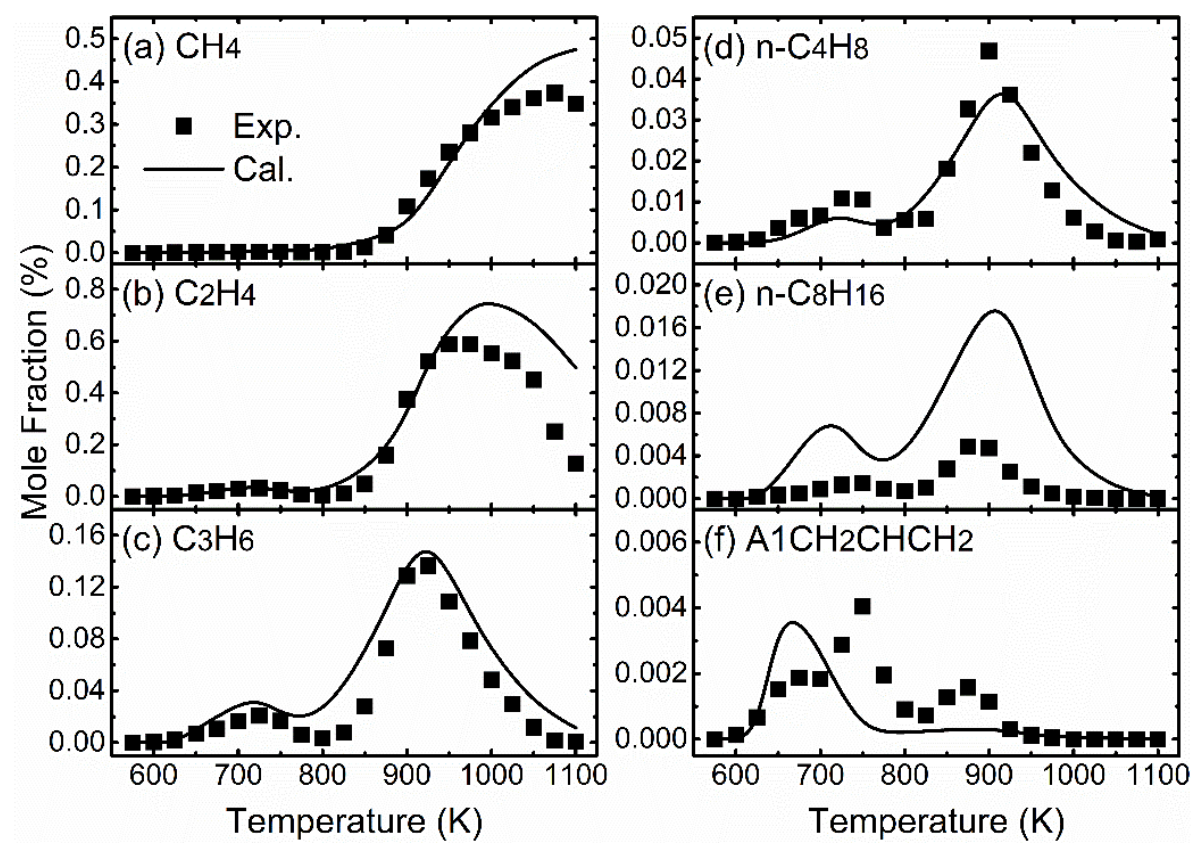

Fig. 6 Comparison between the measured (symbols) and modeling results (lines) of: $\mathrm{CH}_{4}(\mathrm{a}), \mathrm{C}_{2} \mathrm{H}_{4}$ (b), $\mathrm{C}_{3} \mathrm{H}_{6}(\mathrm{c}), \mathrm{n}-\mathrm{C}_{4} \mathrm{H}_{8}(\mathrm{~d}), \mathrm{n}-\mathrm{C}_{8} \mathrm{H}_{16}$ (e), and $\mathrm{AlCH}_{2} \mathrm{CHCH}_{2}$ (f) using the reaction model of the present work, at $p=1 \mathrm{~atm}$ and $\varphi=2.0$.

Figure 7 shows the simulated and experimental results of two oxygenated species: acetaldehyde $\left(\mathrm{CH}_{3} \mathrm{CHO}\right)$ and phenol $(\mathrm{A} 1 \mathrm{OH})$. It can be seen that the reaction model can successfully predict the generation of $\mathrm{CH}_{3} \mathrm{CHO}$ and $\mathrm{AlOH}$ in the NTC region, with an underprediction of $\mathrm{A} 1 \mathrm{OH}$. ROP analysis reveals that phenyl radicals (A1-), the precursor of $\mathrm{A} 1 \mathrm{OH}$, is generated less at low temperatures, as shown in Fig. 3. Both predictions of $\mathrm{CH}_{3} \mathrm{CHO}$ and $\mathrm{A} 1 \mathrm{OH}$ reveal a shifted peak compared to the experimental results at higher temperatures, which is mainly effected by the underprediction and peaking skewing of $\mathrm{C}_{2} \mathrm{H}_{5}$ and $\mathrm{A} 1 \mathrm{CHO}$, respectively. 

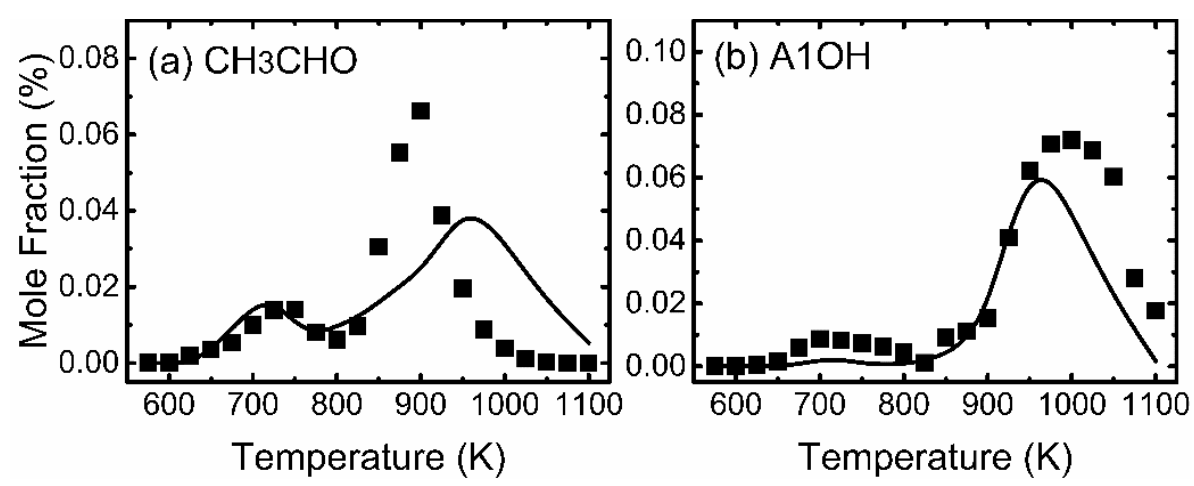

Fig. 7 Comparison between the measured (symbols) and modeling results (lines) of: $\mathrm{CH}_{3} \mathrm{CHO}$ (a) and $\mathrm{A} 1 \mathrm{OH}$ (b) using the reaction model of the present work, at $p=1 \mathrm{~atm}$ and $\varphi=2.0$.

\subsection{Ignition delay time}

The comparison between experimental and simulated data of the ignition delay time is displayed in Fig. 8. In general, the present model predicts good results of ignition delay time, especially on tendencies. The curve maintains an "S" shape profile as the temperature is decreasing through the NTC region, which is in agreement with the results on ignition delay times for n-decane [1] and n-dodecane [3], respectively. This reveals that the ignition of the surrogate selected in the present work is mainly led by the kinetics of n-dodecane, the long-chain alkane. Although the predicted NTC region is shifted a bit towards higher temperatures, the measured ignition delay time is more or less overestimated by the model except at the highest temperatures. It should be mentioned that the deviations between experiment and simulation are not caused by non-ideal ignition behavior in the experiments; the pressure profile does not broaden the NTC-regime.

The comparison between the surrogate fuel ignition $\left(\varphi=1.0,16\right.$ bar, dilution 1:2 with $\left.\mathrm{N}_{2}\right)$ and jet fuel ignition at the same mixture conditions is also displayed in Fig. 8. Both of these two curves maintain the same tendency, and their NTC transition appears at a similar temperature $(850 \mathrm{~K})$, although the practical jet fuel exhibits a less pronounced NTC-effect. This less pronounced NTC-effect is probably due to the presence of iso-paraffinic species and higher aromatic content in 
the jet fuel.

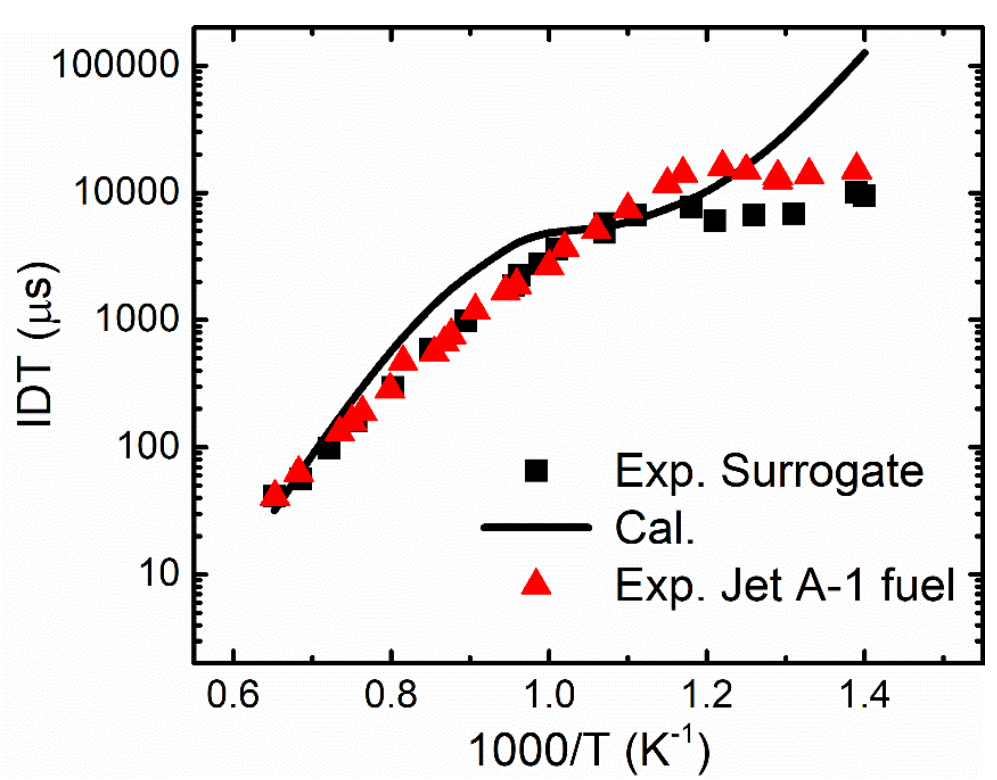

Fig. 8 Comparison between measured (symbols) and calculated (solid curve) ignition delay time data of surrogate fuel and jet fuel, respectively. Square - experimental data for surrogate fuel; solid line calculated results of surrogate fuel using the mechanism of the present work; triangle - experimental data for Jet A-1 fuel. Experiments were performed for $\varphi=1.0, p=16$ bar, and a dilution 1:2 with $\mathrm{N}_{2}$.

\subsection{Laminar flame speed}

The results of the measured laminar burning velocities and the calculated flame speeds of the surrogate are shown in Fig. 9. For comparison, the data of two pure surrogate components, n-dodecane and n-propylbenzene, as well as experimental data of a Jet A-1 are included. The simulations show a good prediction of the laminar flame speed data, especially for n-propylbenzene, with a slight underprediction over the whole $\varphi$-range for all fuels. Although the deviations in the $\varphi$-range from 0.6 to 1.5 (and up to 1.7 for n-propylbenzene) are at about $10 \%$, thus being satisfying for flame speed calculations, the experimental data are throughout underpredicted. A comparison to literature data in Fig. 10 for n-dodecane and n-propylbenzene, measured each using the counterflow technique, shows even slightly higher values for the burning velocity. 
All experimental burning velocities of the specific fuels are very close to each other; thus indicating a similar combustion behavior of the surrogate as it is found for the components as well as for the considered Jet A-1 fuel. Only for n-dodecane, slightly higher values were measured which is caused by its linear structure. As it is visible from Fig. 9, this behavior is not found in the simulations due to two reasons: (i) In general, the experimental values are very close by, to predict such small differences is quite difficult; and (ii) the sub-mechanism for n-propylbenzene is superiorly optimized than the one for n-dodecane (see Liu et al. [38]). So presently the surrogate mechanism predicts n-propylbenzene better than n-dodecane leading to the result that the mechanism cannot reflect the typical structure dependency of the burning velocity.

The uncertainties of the measured burning velocities result predominantly from the determination of the cone angle and range between $2 \%$ and $13 \%$, depending on the $\varphi$-value. Furthermore, the inaccuracy of the mass flow controllers, possible pressure fluctuations, and the treatment of the fuel as ideal gas have also an influence on the uncertainties. Although these sources of errors are less important for the determination of the burning velocities they may cause uncertainties within the determination of the $\varphi$-value of $2 \%$ to $10 \%$. All uncertainties are calculated from the maximum error. Since the uncertainties are similar for all fuels and to have a clear overview in Fig. 9, error bars are drawn only for a few data points. 


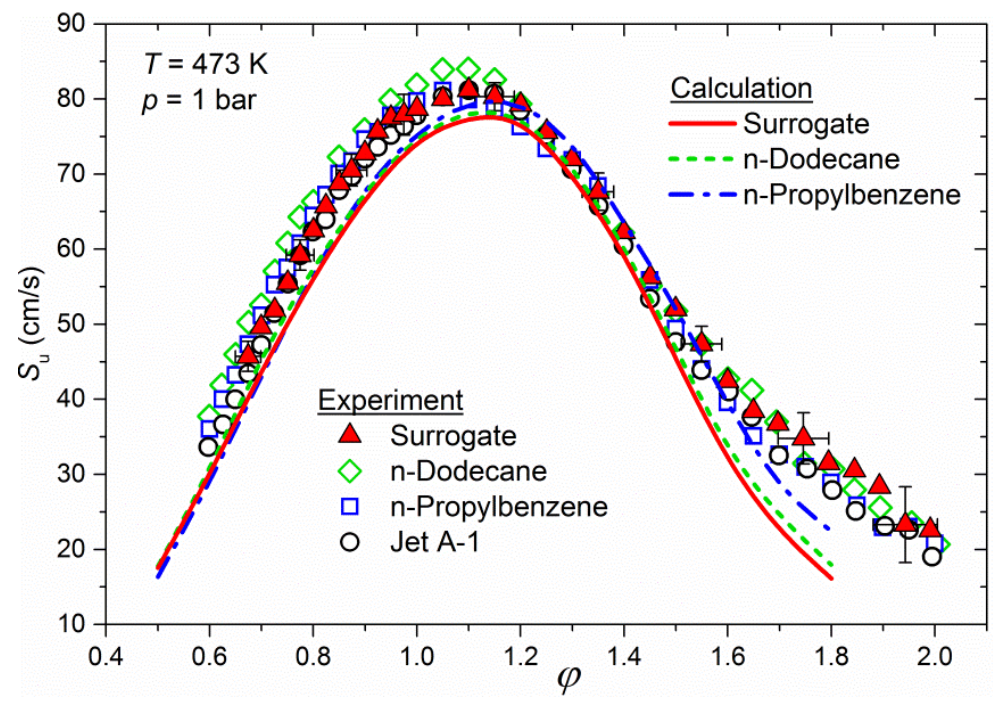

Fig. 9 Measured (symbols) and calculated (curves) laminar burning velocities of the surrogate (triangles - red, solid line) and, for comparison, of n-dodecane (diamonds - green, dashed line), n-propylbenzene (squares - blue, dashed-dotted line), and Jet A-1 (circles). All data given at $T=473 \mathrm{~K}$ and $p=1$ bar.

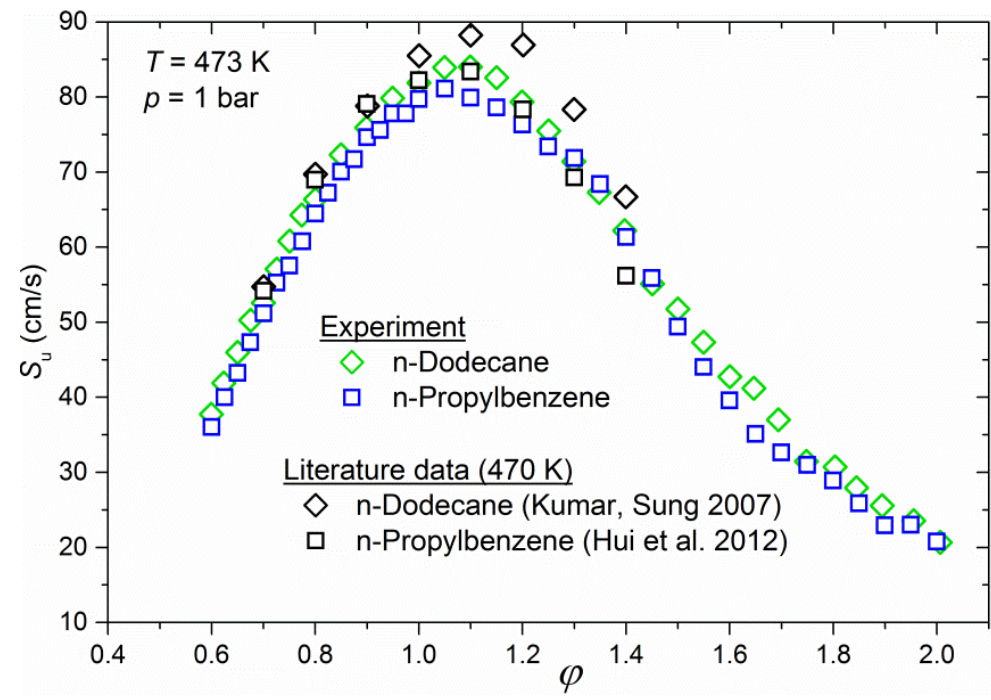

Fig. 10 Comparison for the measurement of the laminar burning velocity of $n$-dodecane and n-propylbenzene, respectively with literature values from Kumar and Sung [56] as well as from Hui et al. [57]

\section{Conclusions}

To describe the combustion characteristics of a crude-oil based jet fuel, a three-component 
surrogate fuel (n-dodecane 66.2\%, NPB 15.8\% and T135MCH 18.0\% in mol) was studied in three different types of reactors. First, in a jet stirred reactor (JSR, species profiles) at temperatures ranging between $575-1100 \mathrm{~K}, \varphi=2.0$, and ambient pressures. Second, in a shock tube device (ignition delay time) at temperatures ranging between $700-1600 \mathrm{~K}$, at $\varphi=1.0$ and pressures around 16 bar, respectively. Third, furthermore, laminar burning velocities were determined in burner test rig within a large fuel equivalence range, with $\varphi=0.6$ to 2.0 , at a preheat temperature of $T_{\text {pre }}=473 \mathrm{~K}$ and at $p=$ 1 bar. A detailed kinetic mechanism involving 401 species and 2838 reactions was developed by exploiting the experimental data as obtained within the present work. In general, a reasonable, mostly good agreement with respect to the measured species profiles, ignition delay times, and burning velocities was achieved. From the performed flux and sensitivity analysis, H-abstraction reactions from methyl were revealed as the main consumption channels of the surrogate components; furthermore, these compounds affected each other in these major channels. N-propylbenzene is preferably consumed through $\mathrm{H}$-abstraction to $\mathrm{AlCH}_{2} \mathrm{CHCH}_{3}$, whereas 1,3,5-trimethylcyclohexane

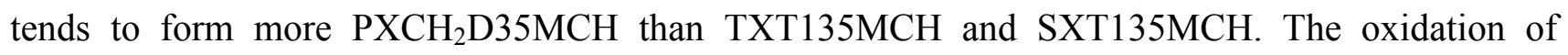
n-dodecane is first yielding six specific $\mathrm{C}_{12} \mathrm{H}_{25}$ radicals. These radicals are consumed through reactions with peroxides involved and decomposition reactions at low and high temperatures, respectively. The existence of the NTC effect was observed, as seen e.g. from the mol fraction profiles; this finding is similar to the one observed within the oxidation of previous n-dodecane studies. In addition, the performance of the reaction model developed within the present work was checked against the experimental ignition behavior and laminar burning velocity of the jet fuel surrogate as well as of Jet A-1, showing the applicability of the selected composition of the specific surrogate, since the presented reaction model shows a good agreement with the experimental data. Thus, these experimental results in conjunction with the detailed chemical reaction model developed 
present a comprehensive study of the oxidation of a jet fuel surrogate which will improve the current understanding of the oxidation and combustion of components being of interest for the use in a jet fuel surrogate.

\section{Acknowledgements}

The authors thank for the financial support from Natural Science Foundation of China (No 51476168/91541102), the Ministry of Science and Technology of China (2017YFA0402800), the Recruitment Program of Global Youth Experts, and the Alexander von Humboldt Research Group Linkage. 


\section{References}

[1] P. Dagaut, M. Cathonnet, The ignition, oxidation, and combustion of kerosene: A review of experimental and kinetic modeling, Prog. Energy Combust. Sci. 32 (2006) 48-92.

[2] P. Dagaut, F. Karsenty, G. Dayma, P. Diévart, K. Hadj-Ali, A. Mzé-Ahmed, M. Braun-Unkhoff, J. Herzler, T. Kathrotia, T. Kick, C. Naumann, U. Riedel, L. Thomas, Experimental and detailed kinetic model for the oxidation of a Gas to Liquid (GtL) jet fuel, Combust. Flame 161 (2014) 835-847.

[3] T. Malewicki, S. Gudiyella, K. Brezinsky, Experimental and modeling study on the oxidation of Jet $\mathrm{A}$ and the n-dodecane/iso-octane/n-propylbenzene/1,3,5-trimethylbenzene surrogate fuel, Combust. Flame 160 (2013) 17-30.

[4] M. Braun-Unkhoff, U. Riedel, Alternative fuels in aviation, CEAS Aeronautical J. 6 (2015) 83-93.

[5] S. Riebl, M. Braun-Unkhoff, U. Riedel, A Study on the Emissions of Alternative Aviation Fuels, J. Eng. Gas. Turbines Power-Trans. ASME 139 (2017) 11.

[6] D. Zheng, W.M. Yu, B.J. Zhong, RP-3 aviation kerosene surrogate fuel and the chemical reaction kinetic model, Acta Phys.-Chim. Sin. 31 (2015) 636-642.

[7] T. Edwards, L.Q. Maurice, Surrogate mixtures to represent complex aviation and rocket fuels, J. Propul. Power 17 (2001) 461-466.

[8] J.A. Widegren, T.J. Bruno, Thermal decomposition kinetics of the aviation turbine fuel Jet A, Ind. Eng. Chem. Res. 47 (2008) 4342-4348.

[9] W.J. Pitz, C.J. Mueller, Recent progress in the development of diesel surrogate fuels, Prog. Energy Combust. Sci. 37 (2011) 330-350.

[10] F. Battin-Leclerc, Detailed chemical kinetic models for the low-temperature combustion of hydrocarbons with application to gasoline and diesel fuel surrogates, Prog. Energy Combust. Sci. 34 (2008) 440-498.

[11] M. Saffaripour, A. Veshkini, M. Kholghy, M.J. Thomson, Experimental investigation and detailed modeling of soot aggregate formation and size distribution in laminar coflow diffusion flames of Jet A-1, a synthetic kerosene, and n-decane, Combust. Flame 161 (2014) 848-863.

[12] D. Kang, V. Kalaskar, D. Kim, J. Martz, A. Violi, A. Boehman, Experimental study of autoignition characteristics of Jet-A surrogates and their validation in a motored engine and a constant-volume combustion chamber, Fuel 184 (2016) 565-580.

[13] J. Yu, Z.J. Wang, X.F. Zhuo, W. Wang, X.L. Gou, Surrogate definition and chemical kinetic 
modeling for two different jet aviation fuels, Energy Fuels 30 (2016) 1375-1382.

[14] C.H. Zhang, B. Li, F. Rao, P. Li, X.Y. Li, A shock tube study of the autoignition characteristics of RP-3 jet fuel, Proceedings of the Combustion Institute 35 (2015) 3151-3158.

[15] H.A. Ma, M.Z. Xie, W. Zeng, B.D. Chen, Experimental study on combustion characteristics of Chinese RP-3 kerosene, Chin. J. Aeronaut. 29 (2016) 375-385.

[16] W. Zeng, H. Li, H. Ma, S. Liang, B. Chen, Reduced chemical reaction mechanism of surrogate fuel for RP-3 kerosene, Journal of Propulsion Technology 35 (2014) 1139-1145.

[17] S.H. Li, J.W. Liu, R. Li, F. Wang, N.X. Tan, X.Y. Li, Automatic chemistry mechanism reduction on hydrocarbon fuel combustion, Chem. J. Chin. Univ.-Chin. 36 (2015) 1576-1587.

[18] Y.W. Yan, Y.P. Liu, D. Di, C. Dai, J.H. Li, Simplified Chemical Reaction Mechanism for Surrogate Fuel of Aviation Kerosene and Its Verification, Energy Fuels 30 (2016) 10847-10857.

[19] M.R. Zeng, W.H. Yuan, Y.Z. Wang, W.X. Zhou, L.D. Zhang, F. Qi, Y.Y. Li, Experimental and kinetic modeling study of pyrolysis and oxidation of n-decane, Combust. Flame 161 (2014) 1701-1715.

[20] J.Q. Xu, J.J. Guo, A.K. Liu, J.L. Wang, N.X. Tan, X.Y. Li, Construction of Autoignition Mechanisms for the Combustion of RP-3 Surrogate Fuel and Kinetics Simulation, Acta Phys.-Chim. Sin. 31 (2015) 643-652.

[21] S. Banerjee, R. Tangko, D.A. Sheen, H. Wang, C.T. Bowman, An experimental and kinetic modeling study of n-dodecane pyrolysis and oxidation, Combust. Flame 163 (2016) 12-30.

[22] M.R. Zeng, W.H. Yuan, W. Li, Y. Zhang, Y.Z. Wang, Investigation of n-dodecane pyrolysis at various pressures and the development of a comprehensive combustion model, Energy 155 (2018) 152-161.

[23] K. Narayanaswamy, P. Pepiot, H. Pitsch, A chemical mechanism for low to high temperature oxidation of n-dodecane as a component of transportation fuel surrogates, Combust. Flame 161 (2014) 866-884.

[24] T. Malewicki, K. Brezinsky, Experimental and modeling study on the pyrolysis and oxidation of n-decane and n-dodecane, Proceedings of the Combustion Institute 34 (2013) 361-368.

[25] A. Mze-Ahmed, K. Hadj-Ali, P. Dagaut, G. Dayma, Experimental and Modeling Study of the Oxidation Kinetics of n-Undecane and n-Dodecane in a Jet-Stirred Reactor, Energy Fuels 26 (2012) 4253-4268.

[26] J.M. Desantes, J.J. Lopez, J.M. Garcia-Oliver, D. Lopez-Pintor, Experimental validation and 
analysis of seven different chemical kinetic mechanisms for n-dodecane using a Rapid Compression-Expansion Machine, Combust. Flame 182 (2017) 76-89.

[27] S.S. Vasu, D.F. Davidson, Z. Hong, V. Vasudevan, R.K. Hanson, n-Dodecane oxidation at high-pressures: Measurements of ignition delay times and $\mathrm{OH}$ concentration time-histories, Proceedings of the Combustion Institute 32 (2009) 173-180.

[28] Q.D. Wang, J.B. Wang, J.Q. Li, N.X. Tan, X.Y. Li, Reactive molecular dynamics simulation and chemical kinetic modeling of pyrolysis and combustion of n-dodecane, Combust. Flame 158 (2011) 217-226.

[29] X.X. Hua, J.B. Wang, Q.D. Wang, N.X. Tan, X.Y. Li, Mechanism Construction and Simulation for the High-Temperature Combustion of n-Dodecane, Acta Phys.-Chim. Sin. 27 (2011) 2755-2761.

[30] Y.M. Fang, Q.D. Wang, F. Wang, X.Y. Li, Reduction of the Detailed Kinetic Mechanism for High-Temperature Combustion of n-Dodecane, Acta Phys.-Chim. Sin. 28 (2012) 2536-2542.

[31] X.Q. You, F.N. Egolfopoulos, H. Wang, Detailed and simplified kinetic models of n-dodecane oxidation: The role of fuel cracking in aliphatic hydrocarbon combustion, Proceedings of the Combustion Institute 32 (2009) 403-410.

[32] Z.D. Wang, Y.Y. Li, F. Zhang, L.D. Zhang, W.H. Yuan, Y.Z. Wang, F. Qi, An experimental and kinetic modeling investigation on a rich premixed n-propylbenzene flame at low pressure, Proceedings of the Combustion Institute 34 (2013) 1785-1793.

[33] S. Gudiyella, K. Brezinsky, High pressure study of n-propylbenzene oxidation, Combust. Flame 159 (2012) 940-958.

[34] D. Darcy, M. Mehl, J.M. Simmie, J. Wurmel, W.K. Metcalfe, C.K. Westbrook, W.J. Pitz, H.J. Curran, An experimental and modeling study of the shock tube ignition of a mixture of n-heptane and n-propylbenzene as a surrogate for a large alkyl benzene, Proceedings of the Combustion Institute 34 (2013) 411-418.

[35] D. Darcy, H. Nakamura, C.J. Tobin, M. Mehl, W.K. Metcalfe, W.J. Pitz, C.K. Westbrook, H.J. Curran, An experimental and modeling study of surrogate mixtures of n-propyl- and n-butylbenzene in n-heptane to simulate n-decylbenzene ignition, Combust. Flame 161 (2014) 1460-1473.

[36] S. Gudiyella, K. Brezinsky, The high pressure study of n-propylbenzene pyrolysis, Proceedings of the Combustion Institute 34 (2013) 1767-1774.

[37] W. Yuan, Y. Li, P. Dagaut, Y. Wang, Z. Wang, F. Qi, A comprehensive experimental and kinetic modeling study of n-propylbenzene combustion, Combust. Flame 186 (2017) 178-192. 
[38] Y.-X. Liu, B.-Y. Wang, J.-J. Weng, D. Yu, S. Richter, T. Kick, C. Naumann, M. Braun-Unkhoff, Z.-Y. Tian, A wide-range experimental and modeling study of oxidation and combustion of n-propylbenzene, Combust. Flame 191 (2018) 53-65.

[39] B.Y. Wang, Y.X. Liu, J.J. Weng, P. Glarborg, Z.Y. Tian, New insights in the low-temperature oxidation of acetylene, Proceedings of the Combustion Institute 36 (2017) 355-363.

[40] J.J. Weng, Y.X. Liu, B.Y. Wang, L.L. Xing, L.D. Zhang, Z.Y. Tian, Experimental and kinetic investigation of 1,2,4-trimethylbenzene oxidation at low temperature, Proceedings of the Combustion Institute 36 (2017) 909-917.

[41] T. Kathrotia, C. Naumann, P. Oßwald, M. Köhler, U. Riedel, Kinetics of Ethylene Glycol: The first validated reaction scheme and first measurements of ignition delay times and speciation data, Combust. Flame 179 (2017) 172-184.

[42] S. Richter, T. Kathrotia, C. Naumann, T. Kick, N. Slavinskaya, M. Braun-Unkhoff, U. Riedel, Experimental and modeling study of farnesane, Fuel 215 (2018) 22-29.

[43] J. Herzler, L. Jerig, P. Roth, Shock tube study of the ignition of lean n-heptane/air mixtures at intermediate temperatures and high pressures, Proceedings of the Combustion Institute 30 (2005) $1147-1153$.

[44] R.J. Kee, F.M. Rupley, J.A. Miller, Chemkin-II: A Fortran chemical kinetics package for the analysis of gas-phase chemical kinetics, Report No. SAND89-8009, Sandia National Laboratories, 1989.

[45] H. Eberius, T. Kick, Stabilization of premixed, conical methane flames at high pressure, Berichte der Bunsengesellschaft für physikalische Chemie 96 (1992) 1416-1419.

[46] G. Andrews, D. Bradley, Determination of burning velocities: a critical review, Combust. Flame 18 (1972) 133-153.

[47] T. Kick, J. Herbst, T. Kathrotia, J. Marquetand, M. Braun-Unkhoff, C. Naumann, U. Riedel, An experimental and modeling study of burning velocities of possible future synthetic jet fuels, Energy 43 (2012) 111-123.

[48] D.G. Goodwin, H.K. Moffat, R.L. Speth, "Cantera: An object- oriented software toolkit for chemical kinetics, thermodynamics, and transport processes", http://www.cantera.org, Version 2.2.1., 2016.

[49] R.J. Kee, G. Dixon-Lewis, J. Warnatz, M.E. Coltrin, J.A. Miller, "The Chemkin Transport Database. Report SAND86-8246”, Sandia National Laboratories, Livermore (CA), USA., (1986). 
[50] Z.D. Wang, L.L. Ye, W.H. Yuan, L.D. Zhang, Y.Z. Wang, Z.J. Cheng, F. Zhang, F. Qi, Experimental and kinetic modeling study on methylcyclohexane pyrolysis and combustion, Combust. Flame 161 (2014) 84-100.

[51] H.B. Ning, C.M. Gong, N.X. Tan, Z.R. Li, X.Y. Li, Low- and intermediate-temperature oxidation of ethylcyclohexane: A theoretical study, Combust. Flame 162 (2015) 4167-4182.

[52] M.J. Frisch, et al., Gaussian16, Revision A.03, Gaussian, Inc., Wallingford, CT, 2016.

[53] J.A. Montgomery, M.J. Frisch, J.W. Ochterski, G.A. Petersson, A complete basis set model chemistry. VI. Use of density functional geometries and frequencies, J. Chem. Phys. 110 (1999) 2822-2827.

[54] V. Mokrushin, W. Tsang, Chemrate v.1.5.2; NIST, Ed. Gaithersburg, MD 20899, USA, 2006.

[55] C. Muller, V. Michel, G. Scacchi, G.M. Come, Thergas - a computer-program for the evaluation of thermochemical data of molecules and free-radicals in the gas-phase, J. Chim. Phys.-Chim. Biol. 92 (1995) 1154-1178.

[56] K. Kumar, C.-J. Sung, Laminar flame speeds and extinction limits of preheated n-decane $/ \mathrm{O}_{2} / \mathrm{N}_{2}$ and n-dodecane $/ \mathrm{O}_{2} / \mathrm{N}_{2}$ mixtures, Combust. Flame 151 (2007) 209-224.

[57] X. Hui, A.K. Das, K. Kumar, C.-J. Sung, S. Dooley, F.L. Dryer, Laminar flame speeds and extinction stretch rates of selected aromatic hydrocarbons, Fuel 97 (2012) 695-702. 


\title{
Supplementary Material
}

\section{To}

\section{Combustion study of a RP-3 surrogate fuel}

\author{
Yue-Xi Liu ${ }^{1,2}$, Sandra Richter ${ }^{3}$, Clemens Naumann $^{3}$, Marina Braun-Unkhoff ${ }^{3}$, Zhen-Yu Tian ${ }^{1,2,{ }^{*}}$

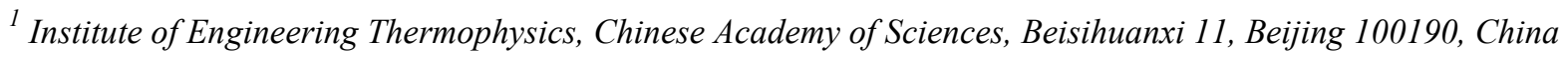 \\ ${ }^{2}$ University of Chinese Academy of Sciences, 19 A Yuquan Rd., Beijing 100049, China \\ ${ }^{3}$ Institute of Combustion Technology, German Aerospace Center (DLR), 70569 Stuttgart, Germany
}

\section{Table of Contents}

Section 1: Original experimental data and the detailed analyzing methods

Section 2: Reactions of T135MCH subset

Section 3: Calculated results of $\mathrm{H}$-abstraction reactions of $\mathrm{T} 135 \mathrm{MCH}$

Section 4: Thermochemical data of T135MCH and its derived species

Section 5: Further mole fraction profiles of surrogate oxidation and the selection of JSR experimental condition.

Section 6: Comparison of the simulated results by using Banerjee's and Mze-Ahmed's n-dodecane model. 


\section{Section 1: Original experimental data and the detailed analyzing methods}

Table S1 Original experimental data of all species measured in the oxidation of surrogate at low temperature $(\varphi=2.0)$.

\begin{tabular}{|c|c|c|c|c|c|c|c|c|c|c|c|c|c|c|c|c|c|c|c|c|c|c|}
\hline \multirow[t]{2}{*}{ Species } & \multicolumn{22}{|c|}{ Mole fractions $(\mathrm{ppm})$ at different temperature $(\mathrm{K})$} \\
\hline & 575 & 600 & 625 & 650 & 675 & 700 & 725 & 750 & 775 & 800 & 825 & 850 & 875 & 900 & 925 & 950 & 975 & 1000 & 1025 & 1050 & 1075 & 1100 \\
\hline $\mathrm{NC}_{12} \mathrm{H}_{26}$ & 3309.5 & 3281.4 & 2000.0 & 1547.4 & 1226.9 & 1140.0 & 1630.0 & 3070.1 & 3270.3 & 3056.4 & 2976.4 & 2389.5 & 1848.1 & 1248.9 & 264.7 & 94.0 & 31.6 & 33.8 & 7.5 & 4.8 & 3.9 & 3.2 \\
\hline 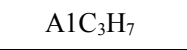 & 791.6 & 786.8 & 721.1 & 626.8 & 602.5 & 615.4 & 646.4 & 716.2 & 791.0 & 766.3 & 720.4 & 714.3 & 618.0 & 453.5 & 228.7 & 121.6 & 59.9 & 33.7 & 11.4 & 2.2 & 0.5 & 0.5 \\
\hline $\mathrm{T} 135 \mathrm{MCH}$ & 899.5 & 888 & 469.3 & 356.4 & 337.1 & 289.7 & 332.6 & 490.1 & 745.4 & 844.6 & 800.6 & 726.4 & 535.1 & 247.3 & 105.3 & 41.4 & 15.6 & 7.5 & 1.5 & 0.2 & 0 & 0 \\
\hline $\mathrm{CO}$ & 34.0 & 66.0 & 832.2 & 2513.0 & 2582.0 & 3046.0 & 2297.4 & 1004.3 & 279.5 & 204.6 & 146.9 & 246.2 & 1633.3 & 3652.4 & 7796.1 & 14221.2 & 20703.6 & 22806.6 & 24839.0 & 29238.4 & 35170.0 & 38098.7 \\
\hline $\mathrm{CO}_{2}$ & 188.6 & 238.6 & 1012.3 & 1268.0 & 1983.2 & 1765.8 & 1470.6 & 1114.5 & 439.2 & 117.9 & 375.4 & 468.0 & 584.7 & 661.6 & 822.6 & 1509.0 & 2305.8 & 2959.0 & 3540.6 & 4212.6 & 4746.3 & 5100.2 \\
\hline $\mathrm{H}_{2}$ & 0.0 & 0.0 & 0.0 & 0.0 & 0.0 & 0.0 & 0.0 & 0.0 & 0.0 & 0.0 & 0.0 & 0.0 & 0.0 & 0.0 & 0.0 & 0.0 & 2772.1 & 3598.1 & 4397.2 & 6988.3 & 11651.8 & 15861.5 \\
\hline $\mathrm{CH}_{4}$ & 0.0 & 0.0 & 1.1 & 7.4 & 10.3 & 17.6 & 22.9 & 21 & 11.3 & 10.9 & 29.1 & 123.1 & 407.4 & 1080.9 & 1729.9 & 2350.6 & 2802.7 & 3158.4 & 3404.8 & 3619.7 & 3728.4 & 3482.9 \\
\hline $\mathrm{C}_{2} \mathrm{H}_{2}$ & 0.0 & 0.0 & 0.0 . & 0.0 . & 0.0 & 0.0 & 2.0 & 5.2 & 0.0 . & 0.0 & 0.0 & 0.0 . & 0.0 . & 0.0 & 25.8 & 47.3 & 0.0 . & 0.0 . & 0.0 . & 0.0 & 0.0 & 0.0 \\
\hline $\mathrm{C}_{2} \mathrm{H}_{4}$ & 1.6 & 10.2 & 42.3 & 145.8 & 213.6 & 304.7 & 320.0 & 233.5 & 73.2 & 43.1 & 108.2 & 488.6 & 1587.2 & 3753.5 & 5234.2 & 5885.6 & 5888.0 & 5544.4 & 5241.7 & 4510.2 & 2515.8 & 1276.4 \\
\hline $\mathrm{C}_{2} \mathrm{H}_{6}$ & 0.0 & 0.0 & 0.6 & 1.5 & 3.3 & 2.7 & 1.9 & 1.7 & 1.4 & 0.6 & 0.9 & 5.7 & 29.1 & 104.0 & 180.0 & 231.2 & 251.3 & 252.3 & 244.3 & 215.5 & 123.0 & 58.8 \\
\hline $\mathrm{aC}_{3} \mathrm{H}_{4}$ & 0.0 . & 0.0 . & 0.0 & 2.3 & 4.1 & 9.0 & 4.8 & 4.0 & 1.4 & 0.0 & 0.0 & 0.0 & 0.8 & 2.4 & 1.6 & 1.7 & 1.2 & 2.3 & 2.6 & 1.3 & 0.0 & 0.0 \\
\hline $\mathrm{pC}_{3} \mathrm{H}_{4}$ & 0.0 & 0.0 & 0.0 & 2.3 & 3.5 & 5.8 & 10.3 & 14.5 & 4.1 & 91.5 & 135.5 & 191.3 & 218.6 & 266.6 & 249.7 & 121.9 & 165.0 & 119.1 & 67.0 & 85.1 & 79.0 & 68.6 \\
\hline $\mathrm{C}_{3} \mathrm{H}_{6}$ & 0.0 & 4.7 & 21.0 & 68.7 & 107.4 & 165.3 & 206.2 & 169.0 & 60.5 & 36.1 & 76.3 & 277.5 & 726.9 & 1288.1 & 1366.4 & 1089.9 & 786.3 & 484.3 & 296.4 & 116.9 & 16.1 & 6.2 \\
\hline $\mathrm{C}_{3} \mathrm{H}_{8}$ & 0.0 & 0.0 & 0.0 & 0.0 & 1.1 & 1.7 & 2.7 & 0.9 & 0.0 & 0.0 & 0.0 & 0.4 & 3.3 & 10.6 & 15.3 & 23.6 & 26.4 & 27.5 & 26.3 & 23.9 & 11.7 & 2.8 \\
\hline $1,3-\mathrm{C}_{4} \mathrm{H}_{6}$ & 0.0 & 0.7 & 3.3 & 6.6 & 7.3 & 8.6 & 25.1 & 54.5 & 15.8 & 14.4 & 16.0 & 19.3 & 23.3 & 35.0 & 95.6 & 153.2 & 128.5 & 110.9 & 71.9 & 59.0 & 23.9 & 0.0 \\
\hline $\mathrm{n}-\mathrm{C}_{4} \mathrm{H}_{8}$ & 0.0 & 1.9 & 8.7 & 37.0 & 30.0 & 67.4 & 108.7 & 106.0 & 37.4 & 56.4 & 58.1 & 180.8 & 326.5 & 467.9 & 361.9 & 219.7 & 128.0 & 61.0 & 27.5 & 5.9 & 2.4 & 0.9 \\
\hline $\mathrm{i}-\mathrm{C}_{4} \mathrm{H}_{8}$ & 0.0 & 0.0 & 1.1 & 4.9 & 9.3 & 4.2 & 4.0 & 3.5 & 1.2 & 1.6 & 4.2 & 18.4 & 20.9 & 77.6 & 31.3 & 23.8 & 19.1 & 12.3 & 8.1 & 7.7 & 3.5 & 3.4 \\
\hline $\mathrm{CH}_{3} \mathrm{CHO}$ & 1.1 & 1.1 & 20.0 & 36.3 & 53.5 & 99.7 & 139.1 & 140.7 & 81.0 & 62.0 & 96.8 & 305.9 & 552.6 & 661.8 & 388.3 & 196.2 & 88.8 & 38.4 & 11.1 & 2.6 & 0.0 & 0.0 \\
\hline $\mathrm{n}-\mathrm{C}_{7} \mathrm{H}_{14}$ & 0.0 & 0.1 & 1.5 & 3.4 & 5.7 & 11.0 & 18.6 & 19.6 & 10.9 & 8.0 & 11.8 & 35.2 & 61.1 & 71.0 & 44.0 & 23.7 & 12.3 & 7.1 & 3.8 & 2.3 & 1.6 & 1.5 \\
\hline $\mathrm{n}-\mathrm{C}_{8} \mathrm{H}_{16}$ & 0.0 & 0.0 & 1.7 & 3.5 & 5.0 & 7.9 & 12.9 & 14.7 & 9.5 & 7.2 & 10.3 & 27.9 & 48.3 & 47.2 & 25.1 & 11.6 & 4.9 & 1.6 & 0.7 & 0.3 & 0.1 & 0.1 \\
\hline $\mathrm{T} 135 \mathrm{MB}$ & 0.4 & 3.0 & 15.9 & 26.8 & 46.8 & 66.1 & 74.6 & 109.8 & 54.4 & 23.6 & 17.7 & 29.3 & 32.3 & 22.1 & 5.1 & 1.4 & 0.3 & 0.0 & 0.0 & 0.0 & 0.0 & 0.0 \\
\hline $\mathrm{A}_{1 \mathrm{CH}_{2} \mathrm{CHCH}_{2}}$ & 0.0 & 1.2 & 6.6 & 15.2 & 18.6 & 23.3 & 28.7 & 40.4 & 19.5 & 9.1 & 7.2 & 12.8 & 15.8 & 11.4 & 3.0 & 1.2 & 0.4 & 0.0 & 0.0 & 0.0 & 0.0 & 0.0 \\
\hline $\mathrm{AlCHCHCH}_{3}$ & 0.5 & 0.7 & 3.7 & 6.9 & 8.1 & 10.0 & 12.5 & 12.7 & 5.4 & 2.7 & 2.9 & 4.3 & 8.4 & 10.6 & 9.4 & 7.2 & 5.0 & 3.7 & 2.3 & 1.1 & 0.0 & 0.0 \\
\hline $\mathrm{A} 1 \mathrm{OH}$ & 16.0 & 18.6 & 60.1 & 349.6 & 534.0 & 637.8 & 765.9 & 833.2 & 516.7 & 309.0 & 82.0 & 91.8 & 112.1 & 152.7 & 328.4 & 589.6 & 551.6 & 620.8 & 686.4 & 602.8 & 280.0 & 177.6 \\
\hline C14H14 & 0.0 & 0.0 & 1.7 & 7.8 & 19.0 & 28.9 & 39.5 & 49.0 & 37.6 & 25.8 & 8.6 & 4.6 & 5.8 & 7.7 & 11.0 & 23.8 & 18.9 & 13.8 & 10.6 & 10.6 & 5.2 & 3.8 \\
\hline
\end{tabular}


The GC and GC-MS techniques were used to quantify and qualify the outlet species. TCD was used to analyze $\mathrm{H}_{2}, \mathrm{CO}_{2} \mathrm{CO}_{2}$ and $\mathrm{CH}_{4}$. The quantification of light hydrocarbons and aromatics was performed by FID with chromatographic columns of $\mathrm{Al}_{2} \mathrm{O}_{3}-\mathrm{KCl}$ and $\mathrm{HP}-\mathrm{INNOWax}$, respectively. The calibration was carried out by injecting known amounts of the standard gases. The newly detected intermediates without standard gas were quantified by using effective carbon number method. The detection threshold of GC was about $0.1 \mathrm{ppm}$ for FID and $10.0 \mathrm{ppm}$ for TCD. The estimated uncertainty was about $\pm 5 \%$ for major species and $\pm 15 \%$ for intermediates.

The calculation method of correction factor by using effective carbon number concept was firstly raised by Scanlon et.al in 1985 [1]. A standard of using effective carbon number method on aromatics quantification in gas chromatography was set by American Society for Testing and Material in 2012 [2]. In gas-chromatograph, response factor is very important and influences the mole fraction results directly. The effective carbon number method shows a relationship between two response factors of two aromatics. There is an equation:

$$
\frac{k(x)}{k(s)}=\frac{E(s)}{E(x)}
$$

$k(x)$ : response factor of unknown species

$k(s)$ : response factor of standard species

$E(x)$ : effective carbon number of unknown species

$E(s)$ : effective carbon number of standard species 
Section 2: Reactions of T135MCH subset

Table S2 Sub-mechanism of T135MCH. $k=A \cdot T^{n} \cdot \exp \left(-E_{a} / R \cdot T\right)$, units are $\mathrm{mol}^{*} \mathrm{~s}^{-1} \mathrm{~cm}^{-3}$ and cal.

\begin{tabular}{|c|c|c|c|}
\hline Reactions & A & $n$ & $\mathrm{E}_{\mathrm{a}}$ \\
\hline \multicolumn{4}{|l|}{ Metatheses and bimolecular initiations } \\
\hline 2597. $\mathrm{T} 135 \mathrm{MCH}+\mathrm{H}=\mathrm{PXCH}_{2} \mathrm{D} 35 \mathrm{MCH}+\mathrm{H}_{2}$ & $8.43 \mathrm{E}+08$ & 1.9 & 8575.9 \\
\hline 2598. $\mathrm{T} 135 \mathrm{MCH}+\mathrm{H}=\mathrm{TXT} 135 \mathrm{MCH}+\mathrm{H}_{2}$ & $1.36 \mathrm{E}+07$ & 2.1 & 4098.6 \\
\hline 2599. $\mathrm{T} 135 \mathrm{MCH}+\mathrm{H}=\mathrm{CH}_{3} \mathrm{SXD} 35 \mathrm{MCH}+\mathrm{H}_{2}$ & $3.12 \mathrm{E}+07$ & 2.1 & 6474.4 \\
\hline 2600. $\mathrm{T} 135 \mathrm{MCH}+\mathrm{O}=\mathrm{PXCH}_{2} \mathrm{D} 35 \mathrm{MCH}+\mathrm{OH}$ & $6.60 \mathrm{E}+06$ & 2.4 & 5504.0 \\
\hline 2601. $\mathrm{T} 135 \mathrm{MCH}+\mathrm{O}=\mathrm{TXT} 135 \mathrm{MCH}+\mathrm{OH}$ & $4.71 \mathrm{E}+05$ & 2.5 & 1110.0 \\
\hline 2602. $\mathrm{T} 135 \mathrm{MCH}+\mathrm{O}=\mathrm{CH}_{3} \mathrm{SXD} 35 \mathrm{MCH}+\mathrm{OH}$ & $1.43 \mathrm{E}+05$ & 2.7 & 2106.0 \\
\hline 2603. $\mathrm{T} 135 \mathrm{MCH}+\mathrm{OH}=\mathrm{PXCH}_{2} \mathrm{D} 35 \mathrm{MCH}+\mathrm{H}_{2} \mathrm{O}$ & $5.64 \mathrm{E}+07$ & 1.9 & -900.8 \\
\hline 2604. $\mathrm{T} 135 \mathrm{MCH}+\mathrm{OH}=\mathrm{TXT} 135 \mathrm{MCH}+\mathrm{H}_{2} \mathrm{O}$ & $1.00 \mathrm{E}+08$ & 1.8 & 2966.0 \\
\hline 2605. $\mathrm{T} 135 \mathrm{MCH}+\mathrm{OH}=\mathrm{CH}_{3} \mathrm{SXD} 35 \mathrm{MCH}+\mathrm{H}_{2} \mathrm{O}$ & $6.10 \mathrm{E}+07$ & 1.8 & -1479.0 \\
\hline 2606. $\mathrm{T} 135 \mathrm{MCH}+\mathrm{O}_{2}=\mathrm{PXCH}_{2} \mathrm{D} 35 \mathrm{MCH}+\mathrm{HO}_{2}$ & $6.00 \mathrm{E}+13$ & 0.0 & 50930.0 \\
\hline 2607. $\mathrm{T} 135 \mathrm{MCH}+\mathrm{O}_{2}=\mathrm{TXT} 135 \mathrm{MCH}+\mathrm{HO}_{2}$ & $1.20 \mathrm{E}+14$ & 0.0 & 44000.0 \\
\hline 2608. $\mathrm{T} 135 \mathrm{MCH}+\mathrm{O}_{2}=\mathrm{CH}_{3} \mathrm{SXD} 35 \mathrm{MCH}+\mathrm{HO}_{2}$ & $1.20 \mathrm{E}+14$ & 0.0 & 47590.0 \\
\hline 2609. $\mathrm{T} 135 \mathrm{MCH}+\mathrm{HO}_{2}=\mathrm{PXCH}_{2} \mathrm{D} 35 \mathrm{MCH}+\mathrm{H}_{2} \mathrm{O}_{2}$ & $9.15 \mathrm{E}+04$ & 2.7 & 17496.0 \\
\hline 2610. $\mathrm{T} 135 \mathrm{MCH}+\mathrm{HO}_{2}=\mathrm{TXT} 135 \mathrm{MCH}+\mathrm{H}_{2} \mathrm{O}_{2}$ & $3.72 \mathrm{E}+04$ & 2.8 & 10500.0 \\
\hline 2611. $\mathrm{T} 135 \mathrm{MCH}+\mathrm{HO}_{2}=\mathrm{CH}_{3} \mathrm{SXD} 35 \mathrm{MCH}+\mathrm{H}_{2} \mathrm{O}_{2}$ & $4.22 \mathrm{E}+02$ & 3.3 & 14998.0 \\
\hline 2612. $\mathrm{T} 135 \mathrm{MCH}+\mathrm{CH}_{3}=\mathrm{PXCH}_{2} \mathrm{D} 35 \mathrm{MCH}+\mathrm{CH}_{4}$ & $1.13 \mathrm{E}+02$ & 3.3 & 13516.0 \\
\hline 2613. $\mathrm{T} 135 \mathrm{MCH}+\mathrm{CH}_{3}=\mathrm{TXT} 135 \mathrm{MCH}+\mathrm{CH}_{4}$ & $5.73 \mathrm{E}+01$ & 3.3 & 9022.0 \\
\hline 2614. $\mathrm{T} 135 \mathrm{MCH}+\mathrm{CH}_{3}=\mathrm{CH}_{3} \mathrm{SXD} 35 \mathrm{MCH}+\mathrm{CH}_{4}$ & $1.00 \mathrm{E}+02$ & 3.2 & 11418.0 \\
\hline \multicolumn{4}{|l|}{ Reactions of $\mathrm{C}_{9} \mathrm{H}_{17}$ radicals } \\
\hline 2615. $\mathrm{PXCH}_{2} \mathrm{D} 35 \mathrm{MCH}=\mathrm{TXT} 135 \mathrm{MCH}$ & $1.15 \mathrm{E}+07$ & 1.0 & 28687.0 \\
\hline 2616. $\mathrm{PXCH}_{2} \mathrm{D} 35 \mathrm{MCH}=\mathrm{CH}_{3} \mathrm{SXD} 35 \mathrm{MCH}$ & $6.00 \mathrm{E}+07$ & 0.9 & 22700.0 \\
\hline 2617. $\mathrm{PXCH}_{2} \mathrm{D} 35 \mathrm{MCH}=\mathrm{S} \mathrm{XC}_{7} \mathrm{H}_{11}-1-46 \mathrm{M}$ & $8.92 \mathrm{E}+11$ & -2.9 & 19897.0 \\
\hline 2618. $\mathrm{PXCH}_{2} \mathrm{D} 35 \mathrm{MCH}=\mathrm{CH}_{2} \mathrm{D} 35 \mathrm{MCH}+\mathrm{H}$ & $8.14 \mathrm{E}+14$ & -2.4 & 21719.0 \\
\hline 2619. $\mathrm{PXCH}_{2} \mathrm{D} 35 \mathrm{MCH}+\mathrm{O}_{2}=\mathrm{CH}_{2} \mathrm{D} 35 \mathrm{MCH}+\mathrm{HO}_{2}$ & $2.40 \mathrm{E}+10$ & 0.0 & 0.0 \\
\hline 2620. $\mathrm{TXT} 135 \mathrm{MCH}=\mathrm{S} \mathrm{XC}_{7} \mathrm{H}_{11}-1-24 \mathrm{M}$ & $7.77 \mathrm{E}+21$ & -3.8 & 22330.0 \\
\hline 2621. $\mathrm{TXT} 135 \mathrm{MCH}=\mathrm{CH}_{2} \mathrm{D} 35 \mathrm{MCH}+\mathrm{H}$ & $5.68 \mathrm{E}+24$ & -5.0 & 28465.0 \\
\hline 2622. $\mathrm{TXT} 135 \mathrm{MCH}=\mathrm{T} 135 \mathrm{MCHE}+\mathrm{H}$ & $1.47 \mathrm{E}+22$ & -4.1 & 24874.0 \\
\hline 2623. $\mathrm{TXT} 135 \mathrm{MCH}+\mathrm{O}_{2}=\mathrm{CH}_{2} \mathrm{D} 35 \mathrm{MCH}+\mathrm{HO}_{2}$ & $2.80 \mathrm{E}-01$ & 3.6 & 11960.0 \\
\hline 2624. $\mathrm{TXT} 135 \mathrm{MCH}+\mathrm{O}_{2}=\mathrm{T} 135 \mathrm{MCHE}+\mathrm{HO}_{2}$ & 4.20E-01 & 3.6 & 11960.0 \\
\hline 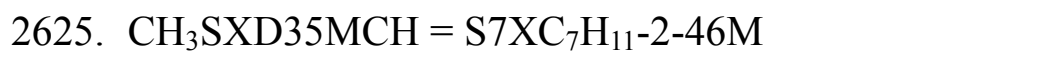 & $4.98 \mathrm{E}+22$ & -4.0 & 21843.0 \\
\hline 2626. $\mathrm{CH}_{3} \mathrm{SXD} 35 \mathrm{MCH}=\mathrm{T} 135 \mathrm{MCHE}+\mathrm{H}$ & $2.06 \mathrm{E}+20$ & -3.8 & 23117.0 \\
\hline 2627. $\mathrm{CH}_{3} \mathrm{SXD} 35 \mathrm{MCH}=\mathrm{D} 35 \mathrm{MCHE}+\mathrm{CH}_{3}$ & $4.24 \mathrm{E}+21$ & -3.9 & 22867.0 \\
\hline 2628. $\mathrm{S} \mathrm{XC}_{7} \mathrm{H}_{11}-1-46 \mathrm{M}(+\mathrm{M})=\mathrm{S} \mathrm{XC}_{5} \mathrm{H}_{8}-1-4 \mathrm{M}+\mathrm{C}_{3} \mathrm{H}_{6}(+\mathrm{M})$ & $3.98 \mathrm{E}+12$ & 0.1 & 27571.6 \\
\hline 2629. $\mathrm{S}_{5} \mathrm{XC}_{5} \mathrm{H}_{8}-1-4 \mathrm{M}(+\mathrm{M})=\mathrm{aC}_{3} \mathrm{H}_{5}+\mathrm{C}_{3} \mathrm{H}_{6}(+\mathrm{M})$ & $3.98 \mathrm{E}+12$ & 0.1 & 27571.6 \\
\hline 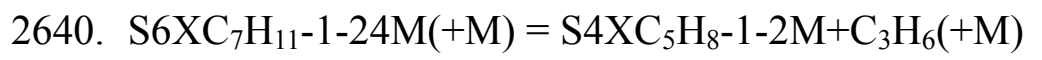 & $4.57 \mathrm{E}+12$ & 0.1 & 24386.4 \\
\hline 2641. $\mathrm{S}_{4} \mathrm{XC}_{5} \mathrm{H}_{8}-1-2 \mathrm{M}(+\mathrm{M})=\mathrm{CH}_{3} \mathrm{CCH}_{2}+\mathrm{C}_{3} \mathrm{H}_{6}(+\mathrm{M})$ & $4.57 \mathrm{E}+12$ & 0.1 & 24386.4 \\
\hline 2659. $\mathrm{S} \mathrm{XC}_{7} \mathrm{H}_{11}-2-46 \mathrm{M}(+\mathrm{M})=\mathrm{S} \mathrm{XC}_{5} \mathrm{H}_{8}-2-4 \mathrm{M}+\mathrm{C}_{3} \mathrm{H}_{6}(+\mathrm{M})$ & $3.98 \mathrm{E}+12$ & 1.1 & 27571.6 \\
\hline 2660. $\mathrm{S}_{5} \mathrm{XC}_{5} \mathrm{H}_{8}-2-4 \mathrm{M}(+\mathrm{M})=\mathrm{CH}_{3} \mathrm{CHCH}+\mathrm{C}_{3} \mathrm{H}_{6}(+\mathrm{M})$ & $3.98 \mathrm{E}+12$ & 1.1 & 27571.6 \\
\hline
\end{tabular}




\begin{tabular}{|c|c|c|c|}
\hline 2630. $\mathrm{CH}_{2} \mathrm{D} 35 \mathrm{MCH}+\mathrm{O}=\mathrm{C}_{3} \mathrm{H}_{6}+\mathrm{C}_{5} \mathrm{H}_{7}-13-2 \mathrm{CH}_{2}+\mathrm{OH}$ & $1.76 \mathrm{E}+11$ & 0.7 & 3250.0 \\
\hline 2631. $\mathrm{CH}_{2} \mathrm{D} 35 \mathrm{MCH}+\mathrm{H}=\mathrm{C}_{3} \mathrm{H}_{6}+\mathrm{C}_{5} \mathrm{H}_{7}-13-2 \mathrm{CH}_{2}+\mathrm{H}_{2}$ & $1.08 \mathrm{E}+05$ & 2.5 & -1900.0 \\
\hline 2632. $\mathrm{CH}_{2} \mathrm{D} 35 \mathrm{MCH}+\mathrm{OH}=\mathrm{C}_{3} \mathrm{H}_{6}+\mathrm{C}_{5} \mathrm{H}_{7}-13-2 \mathrm{CH}_{2}+\mathrm{H}_{2} \mathrm{O}$ & $6.00 \mathrm{E}+06$ & 2.0 & -1520.0 \\
\hline 2633. $\mathrm{CH}_{2} \mathrm{D} 35 \mathrm{MCH}+\mathrm{CH}_{3}=\mathrm{C}_{3} \mathrm{H}_{6}+\mathrm{C}_{5} \mathrm{H}_{7}-13-2 \mathrm{CH}_{2}+\mathrm{CH}_{4}$ & $2.00 \mathrm{E}+11$ & 0.0 & 7300.0 \\
\hline 2634. $\mathrm{CH}_{2} \mathrm{D} 35 \mathrm{MCH}+\mathrm{HO}_{2}=\mathrm{C}_{3} \mathrm{H}_{6}+\mathrm{C}_{5} \mathrm{H}_{7}-13-2 \mathrm{CH}_{2}+\mathrm{H}_{2} \mathrm{O}_{2}$ & $1.28 \mathrm{E}+04$ & 2.6 & 12400.0 \\
\hline 2635. $\mathrm{CH}_{2} \mathrm{D} 35 \mathrm{MCH}+\mathrm{H}=\mathrm{CH}_{2} \mathrm{~S} 2 \mathrm{XD} 35 \mathrm{MCH}+\mathrm{H}_{2}$ & $6.75 \mathrm{E}+05$ & 2.4 & 207.0 \\
\hline 2636. $\mathrm{CH}_{2} \mathrm{D} 35 \mathrm{MCH}+\mathrm{CH}_{3}=\mathrm{CH}_{2} \mathrm{~S} 2 \mathrm{XD} 35 \mathrm{MCH}+\mathrm{CH}_{4}$ & $7.38 \mathrm{E}+00$ & 3.3 & 4002.0 \\
\hline 2637. $\mathrm{CH}_{2} \mathrm{D} 35 \mathrm{MCH}+\mathrm{O}=\mathrm{CH}_{2} \mathrm{~S} 2 \mathrm{XD} 35 \mathrm{MCH}+\mathrm{OH}$ & $1.32 \mathrm{E}+06$ & 2.4 & 1210.0 \\
\hline 2638. $\mathrm{CH}_{2} \mathrm{D} 35 \mathrm{MCH}+\mathrm{OH}=\mathrm{CH}_{2} \mathrm{~S} 2 \mathrm{XD} 35 \mathrm{MCH}+\mathrm{H}_{2} \mathrm{O}$ & $5.53 \mathrm{E}+04$ & 2.6 & -1919.0 \\
\hline 2639. $\mathrm{CH}_{2} \mathrm{~S} 2 \mathrm{XD} 35 \mathrm{MCH}+\mathrm{H}(+\mathrm{M})=\mathrm{CH}_{2} \mathrm{D} 35 \mathrm{MCH}(+\mathrm{M})$ & $4.00 \mathrm{E}+14$ & 0.0 & 0.0 \\
\hline 2642. $\mathrm{T} 135 \mathrm{MCHE}+\mathrm{H}=\mathrm{T} 3 \mathrm{XT} 135 \mathrm{MCH} 1 \mathrm{E}+\mathrm{H}_{2}$ & $1.69 \mathrm{E}+05$ & 2.4 & 207.0 \\
\hline 2643. $\mathrm{T} 135 \mathrm{MCHE}+\mathrm{CH}_{3}=\mathrm{T} 3 \mathrm{XT} 135 \mathrm{MCH} 1 \mathrm{E}+\mathrm{CH}_{4}$ & $1.85 \mathrm{E}+00$ & 3.3 & 4002.0 \\
\hline 2644. $\mathrm{T} 135 \mathrm{MCHE}+\mathrm{O}=\mathrm{T} 3 \mathrm{XT} 135 \mathrm{MCH} 1 \mathrm{E}+\mathrm{OH}$ & $3.30 \mathrm{E}+05$ & 2.4 & 1210.0 \\
\hline 2645. $\mathrm{T} 135 \mathrm{MCHE}+\mathrm{OH}=\mathrm{T} 3 \mathrm{XT} 135 \mathrm{MCH} 1 \mathrm{E}+\mathrm{H}_{2} \mathrm{O}$ & $1.38 \mathrm{E}+04$ & 2.6 & -1919.0 \\
\hline 2646. $\mathrm{T} 3 \mathrm{XT} 135 \mathrm{MCH} 1 \mathrm{E}+\mathrm{H}(+\mathrm{M})=\mathrm{T} 135 \mathrm{MCHE}(+\mathrm{M})$ & $6.65 \mathrm{E}+13$ & 0.0 & 0.0 \\
\hline 2647. $\mathrm{S} 6 \mathrm{XT} 135 \mathrm{MCH} 1 \mathrm{E}+\mathrm{H}(+\mathrm{M})=\mathrm{T} 135 \mathrm{MCHE}(+\mathrm{M})$ & $1.33 \mathrm{E}+14$ & 0.0 & 0.0 \\
\hline 2648. $\mathrm{T} 135 \mathrm{MCHE}+\mathrm{H}=\mathrm{S} 6 \mathrm{XT} 135 \mathrm{MCH} 1 \mathrm{E}+\mathrm{H}_{2}$ & $3.38 \mathrm{E}+05$ & 2.4 & 207.0 \\
\hline 2649. $\mathrm{T} 135 \mathrm{MCHE}+\mathrm{CH}_{3}=\mathrm{S} 6 \mathrm{XT} 135 \mathrm{MCH} 1 \mathrm{E}+\mathrm{CH}_{4}$ & $3.69 \mathrm{E}+00$ & 3.3 & 4002.0 \\
\hline 2650. $\mathrm{T} 135 \mathrm{MCHE}+\mathrm{O}=\mathrm{S} 6 \mathrm{XT135MCH1E}+\mathrm{OH}$ & $6.60 \mathrm{E}+05$ & 2.4 & 1210.0 \\
\hline 2651. $\mathrm{T} 135 \mathrm{MCHE}+\mathrm{OH}=\mathrm{S} 6 \mathrm{XT} 135 \mathrm{MCH} 1 \mathrm{E}+\mathrm{H}_{2} \mathrm{O}$ & $2.76 \mathrm{E}+04$ & 2.6 & -1919.0 \\
\hline 2652. $\mathrm{CH}_{2} \mathrm{~S} 2 \mathrm{XD} 35 \mathrm{MCH}+\mathrm{H}(+\mathrm{M})=\mathrm{T} 135 \mathrm{MCHE}(+\mathrm{M})$ & $2.00 \mathrm{E}+14$ & 0.0 & 0.0 \\
\hline 2653. $\mathrm{T} 135 \mathrm{MCHE}+\mathrm{H}=\mathrm{CH}_{2} \mathrm{~S} 2 \mathrm{XD} 35 \mathrm{MCH}+\mathrm{H}_{2}$ & $1.73 \mathrm{E}+05$ & 2.5 & 2492.0 \\
\hline 2654. $\mathrm{T} 135 \mathrm{MCHE}+\mathrm{CH} 3=\mathrm{CH}_{2} \mathrm{~S} 2 \mathrm{XD} 35 \mathrm{MCH}+\mathrm{CH}_{4}$ & $2.21 \mathrm{E}+00$ & 3.5 & 5675.0 \\
\hline 2655. $\mathrm{T} 135 \mathrm{MCHE}+\mathrm{O}=\mathrm{CH}_{2} \mathrm{~S} 2 \mathrm{XD} 35 \mathrm{MCH}+\mathrm{OH}$ & $4.41 \mathrm{E}+05$ & 2.4 & 3150.0 \\
\hline 2656. $\mathrm{T} 135 \mathrm{MCHE}+\mathrm{OH}=\mathrm{CH}_{2} \mathrm{~S} 2 \mathrm{XD} 35 \mathrm{MCH}+\mathrm{H}_{2} \mathrm{O}$ & $3.12 \mathrm{E}+06$ & 2.0 & -298.0 \\
\hline 2657. $\mathrm{T} 135 \mathrm{MCHE}+\mathrm{HO}_{2}=\mathrm{CH}_{2} \mathrm{~S} 2 \mathrm{XD} 35 \mathrm{MCH}+\mathrm{H}_{2} \mathrm{O}_{2}$ & $9.64 \mathrm{E}+03$ & 2.6 & 13910.0 \\
\hline 2658. $\mathrm{T} 135 \mathrm{MCHE}+\mathrm{O}_{2}=\mathrm{CH}_{2} \mathrm{~S} 2 \mathrm{XD} 35 \mathrm{MCH}+\mathrm{HO}_{2}$ & $3.30 \mathrm{E}+12$ & 0.0 & 39900.0 \\
\hline \multicolumn{4}{|l|}{ Reactions of $\mathrm{C}_{9} \mathrm{H}_{15}$ radicals } \\
\hline 2712. $\mathrm{CH}_{2} \mathrm{~S} 2 \mathrm{XD} 35 \mathrm{MCH}(+\mathrm{M})=\mathrm{CH}_{2} \mathrm{D} 35 \mathrm{MCH} 2 \mathrm{E}+\mathrm{H}(+\mathrm{M})$ & $3.13 \mathrm{E}+08$ & 1.3 & 44697.6 \\
\hline 2713. $\mathrm{CH}_{2} \mathrm{~S} 2 \mathrm{XD} 35 \mathrm{MCH}+\mathrm{O} 2=\mathrm{CH}_{2} \mathrm{D} 35 \mathrm{MCH} 2 \mathrm{E}+\mathrm{HO}_{2}$ & $1.60 \mathrm{E}+12$ & 0.0 & 15160.0 \\
\hline 2661. T3XT135MCH1E $(+\mathrm{M})=\mathrm{T} 135 \mathrm{MCH} 13 \mathrm{E}+\mathrm{H}(+\mathrm{M})$ & $3.13 \mathrm{E}+08$ & 1.3 & 44697.6 \\
\hline 2662. $\mathrm{T} 3 \mathrm{XT} 135 \mathrm{MCH} 1 \mathrm{E}+\mathrm{O} 2=\mathrm{T} 135 \mathrm{MCH} 13 \mathrm{E}+\mathrm{HO}_{2}$ & $1.60 \mathrm{E}+12$ & 0.0 & 15160.0 \\
\hline 2684. $\mathrm{S} 6 \mathrm{XT} 135 \mathrm{MCH} 1 \mathrm{E}(+\mathrm{M})=\mathrm{T} 135 \mathrm{MCH} 13 \mathrm{E}+\mathrm{H}(+\mathrm{M})$ & $3.13 \mathrm{E}+08$ & 1.3 & 44697.6 \\
\hline 2685. S6XT135MCH1E $+\mathrm{O} 2=\mathrm{T} 135 \mathrm{MCH} 13 \mathrm{E}+\mathrm{HO}_{2}$ & $1.60 \mathrm{E}+12$ & 0.0 & 15160.0 \\
\hline \multicolumn{4}{|l|}{ Reactions of $\mathrm{C}_{9} \mathrm{H}_{14}$} \\
\hline 2714. $\mathrm{CH}_{2} \mathrm{D} 35 \mathrm{MCH} 2 \mathrm{E}+\mathrm{H}=\mathrm{S} 4 \mathrm{XCH}_{2} \mathrm{D} 35 \mathrm{MCH} 2 \mathrm{E}+\mathrm{H}_{2}$ & $3.38 \mathrm{E}+05$ & 2.4 & 207.0 \\
\hline 2715. $\mathrm{CH}_{2} \mathrm{D} 35 \mathrm{MCH} 2 \mathrm{E}+\mathrm{CH}_{3}=\mathrm{S} 4 \mathrm{XCH}_{2} \mathrm{D} 35 \mathrm{MCH} 2 \mathrm{E}+\mathrm{CH}_{4}$ & $3.69 \mathrm{E}+00$ & 3.3 & 4002.0 \\
\hline 2716. $\mathrm{CH}_{2} \mathrm{D} 35 \mathrm{MCH} 2 \mathrm{E}+\mathrm{O}=\mathrm{S} 4 \mathrm{XCH}_{2} \mathrm{D} 35 \mathrm{MCH} 2 \mathrm{E}+\mathrm{OH}$ & $6.60 \mathrm{E}+05$ & 2.4 & 1210.0 \\
\hline 2717. $\mathrm{CH}_{2} \mathrm{D} 35 \mathrm{MCH} 2 \mathrm{E}+\mathrm{OH}=\mathrm{S} 4 \mathrm{XCH}_{2} \mathrm{D} 35 \mathrm{MCH} 2 \mathrm{E}+\mathrm{H}_{2} \mathrm{O}$ & $2.76 \mathrm{E}+04$ & 2.6 & -1919.0 \\
\hline 2718. $\mathrm{S} 4 \mathrm{XCH}_{2} \mathrm{D} 35 \mathrm{MCH} 2 \mathrm{E}+\mathrm{H}(+\mathrm{M})=\mathrm{CH}_{2} \mathrm{D} 35 \mathrm{MCH} 2 \mathrm{E}(+\mathrm{M})$ & $1.33 \mathrm{E}+13$ & 0.0 & 0.0 \\
\hline 2719. $\mathrm{CH}_{2} \mathrm{D} 35 \mathrm{MCH} 2 \mathrm{E}+\mathrm{H}=\mathrm{S} 6 \mathrm{XCH}_{2} \mathrm{D} 35 \mathrm{MCH} 2 \mathrm{E}+\mathrm{H}_{2}$ & $3.38 \mathrm{E}+05$ & 2.4 & 207.0 \\
\hline 2720. $\mathrm{CH}_{2} \mathrm{D} 35 \mathrm{MCH} 2 \mathrm{E}+\mathrm{CH}_{3}=\mathrm{S} 6 \mathrm{XCH}_{2} \mathrm{D} 35 \mathrm{MCH} 2 \mathrm{E}+\mathrm{CH}_{4}$ & $3.69 \mathrm{E}+00$ & 3.3 & 4002.0 \\
\hline 2721. $\mathrm{CH}_{2} \mathrm{D} 35 \mathrm{MCH} 2 \mathrm{E}+\mathrm{O}=\mathrm{S} 6 \mathrm{XCH}_{2} \mathrm{D} 35 \mathrm{MCH} 2 \mathrm{E}+\mathrm{OH}$ & $6.60 \mathrm{E}+05$ & 2.4 & 1210.0 \\
\hline 2722. $\mathrm{CH}_{2} \mathrm{D} 35 \mathrm{MCH} 2 \mathrm{E}+\mathrm{OH}=\mathrm{S} 6 \mathrm{XCH}_{2} \mathrm{D} 35 \mathrm{MCH} 2 \mathrm{E}+\mathrm{H}_{2} \mathrm{O}$ & $2.76 \mathrm{E}+04$ & 2.6 & -1919.0 \\
\hline 2723. $\mathrm{S} 6 \mathrm{XCH}_{2} \mathrm{D} 35 \mathrm{MCH} 2 \mathrm{E}+\mathrm{H}(+\mathrm{M})=\mathrm{CH}_{2} \mathrm{D} 35 \mathrm{MCH} 2 \mathrm{E}(+\mathrm{M})$ & $1.33 \mathrm{E}+13$ & 0.0 & 0.0 \\
\hline 2663. $\mathrm{T} 135 \mathrm{MCH} 13 \mathrm{E}+\mathrm{H}=\mathrm{T} 5 \mathrm{XT} 135 \mathrm{MCH} 13 \mathrm{E}+\mathrm{H}_{2}$ & $1.69 \mathrm{E}+05$ & 2.4 & 207.0 \\
\hline
\end{tabular}




\begin{tabular}{|c|c|c|c|}
\hline 2664. $\mathrm{T} 135 \mathrm{MCH} 13 \mathrm{E}+\mathrm{CH}_{3}=\mathrm{T} 5 \mathrm{XT} 135 \mathrm{MCH} 13 \mathrm{E}+\mathrm{CH}_{4}$ & $1.85 \mathrm{E}+00$ & 3.3 & 4002.0 \\
\hline 2665. T135MCH13E+O = T5XT135MCH13E+OH & $3.30 \mathrm{E}+05$ & 2.4 & 1210.0 \\
\hline 2666. $\mathrm{T} 135 \mathrm{MCH} 13 \mathrm{E}+\mathrm{OH}=\mathrm{T} 5 \mathrm{XT} 135 \mathrm{MCH} 13 \mathrm{E}+\mathrm{H}_{2} \mathrm{O}$ & $1.38 \mathrm{E}+04$ & 2.6 & -1919.0 \\
\hline 2667. T5XT135MCH13E $+\mathrm{H}(+\mathrm{M})=\mathrm{T} 135 \mathrm{MCH} 13 \mathrm{E}(+\mathrm{M})$ & $6.65 \mathrm{E}+13$ & 0.0 & 0.0 \\
\hline 2670. $\mathrm{S} 6 \mathrm{XT135MCH13E}+\mathrm{H}(+\mathrm{M})=\mathrm{T} 135 \mathrm{MCH} 13 \mathrm{E}(+\mathrm{M})$ & $1.33 \mathrm{E}+14$ & 0.0 & 0.0 \\
\hline 2671. $\mathrm{T} 135 \mathrm{MCH} 13 \mathrm{E}+\mathrm{H}=\mathrm{S} 6 \mathrm{XT} 135 \mathrm{MCH} 13 \mathrm{E}+\mathrm{H}_{2}$ & $3.38 \mathrm{E}+05$ & 2.4 & 207.0 \\
\hline 2672. $\mathrm{T} 135 \mathrm{MCH} 13 \mathrm{E}+\mathrm{CH}_{3}=\mathrm{S} 6 \mathrm{XT} 135 \mathrm{MCH} 13 \mathrm{E}+\mathrm{CH}_{4}$ & $3.69 \mathrm{E}+00$ & 3.3 & 4002.0 \\
\hline 2673. T135MCH13E+O = S6XT135MCH13E+OH & $6.60 \mathrm{E}+05$ & 2.4 & 1210.0 \\
\hline 2674. $\mathrm{T} 135 \mathrm{MCH} 13 \mathrm{E}+\mathrm{OH}=\mathrm{S} 6 \mathrm{XT} 135 \mathrm{MCH} 13 \mathrm{E}+\mathrm{H}_{2} \mathrm{O}$ & $2.76 \mathrm{E}+04$ & 2.6 & -1919.0 \\
\hline 2677. $\mathrm{T} 135 \mathrm{MCH} 13 \mathrm{E}+\mathrm{H}=\mathrm{S} 4 \mathrm{XCH}_{2} \mathrm{D} 35 \mathrm{MCH} 2 \mathrm{E}+\mathrm{H}_{2}$ & $1.73 \mathrm{E}+05$ & 2.5 & 2492.0 \\
\hline 2678. $\mathrm{T} 135 \mathrm{MCH} 13 \mathrm{E}+\mathrm{CH}_{3}=\mathrm{S} 4 \mathrm{XCH}_{2} \mathrm{D} 35 \mathrm{MCH} 2 \mathrm{E}+\mathrm{CH}_{4}$ & $2.21 \mathrm{E}+00$ & 3.5 & 5675.0 \\
\hline 2679. $\mathrm{T} 135 \mathrm{MCH} 13 \mathrm{E}+\mathrm{O}=\mathrm{S} 4 \mathrm{XCH}_{2} \mathrm{D} 35 \mathrm{MCH} 2 \mathrm{E}+\mathrm{OH}$ & $4.41 \mathrm{E}+05$ & 2.4 & 3150.0 \\
\hline 2680. $\mathrm{T} 135 \mathrm{MCH} 13 \mathrm{E}+\mathrm{OH}=\mathrm{S} 4 \mathrm{XCH}_{2} \mathrm{D} 35 \mathrm{MCH} 2 \mathrm{E}+\mathrm{H}_{2} \mathrm{O}$ & $3.12 \mathrm{E}+06$ & 2.0 & -298.0 \\
\hline 2681. $\mathrm{T} 135 \mathrm{MCH} 13 \mathrm{E}+\mathrm{HO}_{2}=\mathrm{S} 4 \mathrm{XCH}_{2} \mathrm{D} 35 \mathrm{MCH} 2 \mathrm{E}+\mathrm{H}_{2} \mathrm{O}_{2}$ & $9.64 \mathrm{E}+03$ & 2.6 & 13910.0 \\
\hline 2682. $\mathrm{T} 135 \mathrm{MCH} 13 \mathrm{E}+\mathrm{O}_{2}=\mathrm{S} 4 \mathrm{XCH}_{2} \mathrm{D} 35 \mathrm{MCH} 2 \mathrm{E}+\mathrm{HO}_{2}$ & $3.30 \mathrm{E}+12$ & 0.0 & 39900.0 \\
\hline 2683. $\mathrm{S} 4 \mathrm{XCH}_{2} \mathrm{D} 35 \mathrm{MCH} 2 \mathrm{E}+\mathrm{H}(+\mathrm{M})=\mathrm{T} 135 \mathrm{MCH} 13 \mathrm{E}(+\mathrm{M})$ & $2.00 \mathrm{E}+14$ & 0.0 & 0.0 \\
\hline 2686. $\mathrm{T} 135 \mathrm{MCH} 13 \mathrm{E}+\mathrm{H}=\mathrm{S} 6 \mathrm{XCH}_{2} \mathrm{D} 35 \mathrm{MCH} 2 \mathrm{E}+\mathrm{H}_{2}$ & $1.73 \mathrm{E}+05$ & 2.5 & 2492.0 \\
\hline 2687. $\mathrm{T} 135 \mathrm{MCH} 13 \mathrm{E}+\mathrm{CH}_{3}=\mathrm{S} 6 \mathrm{XCH}_{2} \mathrm{D} 35 \mathrm{MCH} 2 \mathrm{E}+\mathrm{CH}_{4}$ & $2.21 \mathrm{E}+00$ & 3.5 & 5675.0 \\
\hline 2688. $\mathrm{T} 135 \mathrm{MCH} 13 \mathrm{E}+\mathrm{O}=\mathrm{S} 6 \mathrm{XCH}_{2} \mathrm{D} 35 \mathrm{MCH} 2 \mathrm{E}+\mathrm{OH}$ & $4.41 \mathrm{E}+05$ & 2.4 & 3150.0 \\
\hline 2689. $\mathrm{T} 135 \mathrm{MCH} 13 \mathrm{E}+\mathrm{OH}=\mathrm{S} 6 \mathrm{XCH}_{2} \mathrm{D} 35 \mathrm{MCH} 2 \mathrm{E}+\mathrm{H}_{2} \mathrm{O}$ & $3.12 \mathrm{E}+06$ & 2.0 & -298.0 \\
\hline 2690. $\mathrm{T} 135 \mathrm{MCH} 13 \mathrm{E}+\mathrm{HO}_{2}=\mathrm{S} 6 \mathrm{XCH}_{2} \mathrm{D} 35 \mathrm{MCH} 2 \mathrm{E}+\mathrm{H}_{2} \mathrm{O}_{2}$ & $9.64 \mathrm{E}+03$ & 2.6 & 13910.0 \\
\hline 2691. $\mathrm{T} 135 \mathrm{MCH} 13 \mathrm{E}+\mathrm{O}_{2}=\mathrm{S} 6 \mathrm{XCH}_{2} \mathrm{D} 35 \mathrm{MCH} 2 \mathrm{E}+\mathrm{HO}_{2}$ & $3.30 \mathrm{E}+12$ & 0.0 & 39900.0 \\
\hline 2692. $\mathrm{S} 6 \mathrm{XCH}_{2} \mathrm{D} 35 \mathrm{MCH} 2 \mathrm{E}+\mathrm{H}(+\mathrm{M})=\mathrm{T} 135 \mathrm{MCH} 13 \mathrm{E}(+\mathrm{M})$ & $2.00 \mathrm{E}+14$ & 0.0 & 0.0 \\
\hline \multicolumn{4}{|l|}{ Reactions of $\mathrm{C}_{9} \mathrm{H}_{13}$ radicals } \\
\hline 2668. T5XT135MCH13E $(+\mathrm{M})=\mathrm{T} 135 \mathrm{MB}+\mathrm{H}(+\mathrm{M})$ & $3.13 \mathrm{E}+08$ & 1.3 & 44697.6 \\
\hline 2669. $\mathrm{T} 5 \mathrm{XT} 135 \mathrm{MCH} 13 \mathrm{E}+\mathrm{O}_{2}=\mathrm{T} 135 \mathrm{MB}+\mathrm{HO}_{2}$ & $1.60 \mathrm{E}+12$ & 0.0 & 15160.0 \\
\hline 2675. $\mathrm{S} 6 \mathrm{XT} 135 \mathrm{MCH} 13 \mathrm{E}+\mathrm{O}_{2}=\mathrm{T} 135 \mathrm{MB}+\mathrm{HO}_{2}$ & $1.60 \mathrm{E}+12$ & 0.0 & 15160.0 \\
\hline 2676. $\mathrm{S} 6 \mathrm{XT135MCH13E}(+\mathrm{M})=\mathrm{T} 135 \mathrm{MB}+\mathrm{H}(+\mathrm{M})$ & $3.13 \mathrm{E}+08$ & 1.3 & 44697.6 \\
\hline 2724. $\mathrm{S} 4 \mathrm{XCH}_{2} \mathrm{D} 35 \mathrm{MCH} 2 \mathrm{E}+\mathrm{O}_{2}=\mathrm{CH}_{2} \mathrm{D} 35 \mathrm{MCH} 24 \mathrm{E}+\mathrm{HO}_{2}$ & $1.60 \mathrm{E}+12$ & 0.0 & 15160.0 \\
\hline 2725. $\mathrm{S} 4 \mathrm{XCH}_{2} \mathrm{D} 35 \mathrm{MCH} 2 \mathrm{E}(+\mathrm{M})=\mathrm{CH}_{2} \mathrm{D} 35 \mathrm{MCH} 24 \mathrm{E}+\mathrm{H}(+\mathrm{M})$ & $3.13 \mathrm{E}+08$ & 1.3 & 44697.6 \\
\hline 2726. $\mathrm{D} 35 \mathrm{MB} 1 \mathrm{CH}_{2}+\mathrm{H}(+\mathrm{M})=\mathrm{CH}_{2} \mathrm{D} 35 \mathrm{MCH} 24 \mathrm{E}(+\mathrm{M})$ & $4.98 \mathrm{E}+11$ & 0.6 & -436.0 \\
\hline 2727. $\mathrm{CH}_{2} \mathrm{D} 35 \mathrm{MCH} 24 \mathrm{E}+\mathrm{H}=\mathrm{D} 35 \mathrm{MB} \mathrm{CH}_{2}+\mathrm{H}_{2}$ & $6.47 \mathrm{E}+00$ & 4.0 & 3394.0 \\
\hline 2728. $\mathrm{CH}_{2} \mathrm{D} 35 \mathrm{MCH} 24 \mathrm{E}+\mathrm{CH}_{3}=\mathrm{D} 35 \mathrm{MB}_{1} \mathrm{CH}_{2}+\mathrm{CH}_{4}$ & $3.16 \mathrm{E}+11$ & 0.0 & 9500.0 \\
\hline 2729. $\mathrm{CH}_{2} \mathrm{D} 35 \mathrm{MCH} 24 \mathrm{E}+\mathrm{O}=\mathrm{D} 35 \mathrm{MB}^{-\mathrm{CH}_{2}}+\mathrm{OH}$ & $6.30 \mathrm{E}+11$ & 0.0 & 0.0 \\
\hline 2730. $\mathrm{CH}_{2} \mathrm{D} 35 \mathrm{MCH} 24 \mathrm{E}+\mathrm{HO}_{2}=\mathrm{D} 35 \mathrm{MB} 1 \mathrm{CH}_{2}+\mathrm{H}_{2} \mathrm{O}_{2}$ & $1.30 \mathrm{E}+11$ & 0.0 & 14070.0 \\
\hline 2731. $\mathrm{CH}_{2} \mathrm{D} 35 \mathrm{MCH} 24 \mathrm{E}+\mathrm{OH}=\mathrm{D} 35 \mathrm{MB} 1 \mathrm{CH}_{2}+\mathrm{H}_{2} \mathrm{O}$ & $1.77 \mathrm{E}+05$ & 2.4 & -602.0 \\
\hline 2732. $\mathrm{CH}_{2} \mathrm{D} 35 \mathrm{MCH} 24 \mathrm{E}+\mathrm{O}_{2}=\mathrm{D} 35 \mathrm{MB} 1 \mathrm{CH} 2+\mathrm{HO}_{2}$ & $1.81 \mathrm{E}+12$ & 0.0 & 39717.0 \\
\hline 2733. $\mathrm{S} 6 \mathrm{XCH}_{2} \mathrm{D} 35 \mathrm{MCH} 2 \mathrm{E}+\mathrm{O}_{2}=\mathrm{CH}_{2} \mathrm{D} 35 \mathrm{MCH} 25 \mathrm{E}+\mathrm{HO}_{2}$ & $1.60 \mathrm{E}+12$ & 0.0 & 15160.0 \\
\hline 2734. $\mathrm{S} 6 \mathrm{XCH}_{2} \mathrm{D} 35 \mathrm{MCH} 2 \mathrm{E}(+\mathrm{M})=\mathrm{CH}_{2} \mathrm{D} 35 \mathrm{MCH} 25 \mathrm{E}+\mathrm{H}(+\mathrm{M})$ & $3.13 \mathrm{E}+08$ & 1.3 & 44697.6 \\
\hline 2735. D35MB1CH${ }_{2}+\mathrm{H}(+\mathrm{M})=\mathrm{CH}_{2} \mathrm{D} 35 \mathrm{MCH} 25 \mathrm{E}(+\mathrm{M})$ & $6.44 \mathrm{E}+12$ & 0.3 & -333.0 \\
\hline 2736. $\mathrm{CH}_{2} \mathrm{D} 35 \mathrm{MCH} 25 \mathrm{E}+\mathrm{H}=\mathrm{D} 35 \mathrm{MB} 1 \mathrm{CH}_{2}+\mathrm{H}_{2}$ & $6.47 \mathrm{E}+00$ & 4.0 & 3394.0 \\
\hline 2737. $\mathrm{CH}_{2} \mathrm{D} 35 \mathrm{MCH} 25 \mathrm{E}+\mathrm{CH}_{3}=\mathrm{D} 35 \mathrm{MB}_{1} \mathrm{CH}_{2}+\mathrm{CH}_{4}$ & $3.16 \mathrm{E}+11$ & 0.0 & 9500.0 \\
\hline 2738. $\mathrm{CH}_{2} \mathrm{D} 35 \mathrm{MCH} 25 \mathrm{E}+\mathrm{O}=\mathrm{D} 35 \mathrm{MB} 1 \mathrm{CH}_{2}+\mathrm{OH}$ & $6.30 \mathrm{E}+11$ & 0.0 & 0.0 \\
\hline 2739. $\mathrm{CH}_{2} \mathrm{D} 35 \mathrm{MCH} 25 \mathrm{E}+\mathrm{HO}_{2}=\mathrm{D} 35 \mathrm{MB} 1 \mathrm{CH}_{2}+\mathrm{H}_{2} \mathrm{O}_{2}$ & $1.30 \mathrm{E}+11$ & 0.0 & 14070.0 \\
\hline 2740. $\mathrm{CH}_{2} \mathrm{D} 35 \mathrm{MCH} 25 \mathrm{E}+\mathrm{OH}=\mathrm{D} 35 \mathrm{MB} \mathrm{CH}_{2}+\mathrm{H}_{2} \mathrm{O}$ & $1.77 \mathrm{E}+05$ & 2.4 & -602.0 \\
\hline 2741. $\mathrm{CH}_{2} \mathrm{D} 35 \mathrm{MCH} 25 \mathrm{E}+\mathrm{O}_{2}=\mathrm{D} 35 \mathrm{MB} 1 \mathrm{CH}_{2}+\mathrm{HO}_{2}$ & $1.81 \mathrm{E}+12$ & 0.0 & 39717.0 \\
\hline
\end{tabular}


Reactions of $\mathrm{C}_{5} \mathrm{H}_{7}-13-2 \mathrm{CH}_{2}$ radicals

2706. $\mathrm{aC}_{3} \mathrm{H}_{4}+\mathrm{aC}_{3} \mathrm{H}_{5}=\mathrm{C}_{5} \mathrm{H}_{7}-13-2 \mathrm{CH}_{2}$

$\begin{array}{lll}1.23 \mathrm{E}+35 & -7.8 & 9930.0\end{array}$

2707. $\mathrm{C}_{5} \mathrm{H}_{7}-13-2 \mathrm{CH}_{2}+\mathrm{H}(+\mathrm{M})=\mathrm{C}_{5} \mathrm{H}_{7}-13-2 \mathrm{M}(+\mathrm{M})$

$\begin{array}{lll}2.00 \mathrm{E}+14 & 0.0 & 0.0\end{array}$

2708. $\mathrm{C}_{5} \mathrm{H}_{7}-13-2 \mathrm{M}+\mathrm{H}=\mathrm{C}_{5} \mathrm{H}_{7}-13-2 \mathrm{CH}_{2}+\mathrm{H}_{2}$

$\begin{array}{lll}1.20 \mathrm{E}+06 & 2.5 & 6760.0\end{array}$

2709. $\mathrm{C}_{5} \mathrm{H}_{7}-13-2 \mathrm{M}+\mathrm{CH}_{3}=\mathrm{C}_{5} \mathrm{H}_{7}-13-2 \mathrm{CH}_{2}+\mathrm{CH}_{4}$

$2.20 \mathrm{E}+00$

3.5

5675.0

2710. $\mathrm{C}_{5} \mathrm{H}_{7}-13-2 \mathrm{M}+\mathrm{OH}=\mathrm{C}_{5} \mathrm{H}_{7}-13-2 \mathrm{CH}_{2}+\mathrm{H}_{2} \mathrm{O}$

$3.10 \mathrm{E}+06$

2.0

$-298.0$

2711. $\mathrm{CH}_{3}+\mathrm{CC}_{5} \mathrm{H}_{7}=\mathrm{C}_{5} \mathrm{H}_{7}-13-2 \mathrm{M}$

$1.00 \mathrm{E}+12$

0.0

0.0

Reactions of D35MCHE

2693. S4XD35MCH1E $+\mathrm{H}(+\mathrm{M})=\mathrm{D} 35 \mathrm{MCHE}(+\mathrm{M})$

2694. D35MCHE $+\mathrm{H}=\mathrm{S} 4 \mathrm{XD} 35 \mathrm{MCH} 1 \mathrm{E}+\mathrm{H}_{2}$

2695. D35MCHE $+\mathrm{CH}_{3}=\mathrm{S} 4 \mathrm{XD} 35 \mathrm{MCH} 1 \mathrm{E}+\mathrm{CH}_{4}$

$2.66 \mathrm{E}+14$

0.0

0.0

$6.75 \mathrm{E}+05$

2.4

207.0

$7.38 \mathrm{E}+00$

3.3

4002.0

$1.32 \mathrm{E}+06$

2.4

1210.0

2697. D35MCHE $+\mathrm{OH}=\mathrm{S} 4 \mathrm{XD} 35 \mathrm{MCH} 1 \mathrm{E}+\mathrm{H}_{2} \mathrm{O}$

$5.53 \mathrm{E}+04$

2.6

$-1919.0$

2698. $\mathrm{S} 4 \mathrm{XD} 35 \mathrm{MCH} 1 \mathrm{E}=\mathrm{C}_{6} \mathrm{H}_{7}-13-5 \mathrm{M}+\mathrm{CH}_{3}$

$4.24 \mathrm{E}+21$

$-3.9$

22867.0

2699. $\mathrm{S} 6 \mathrm{XMCH} 13 \mathrm{E}+\mathrm{H}(+\mathrm{M})=\mathrm{C}_{6} \mathrm{H}_{7}-13-5 \mathrm{M}(+\mathrm{M})$

$2.66 \mathrm{E}+14$

0.0

0.0

2700. $\mathrm{C}_{6} \mathrm{H}_{7}-13-5 \mathrm{M}+\mathrm{H}=\mathrm{S} 6 \mathrm{XMCH} 13 \mathrm{E}+\mathrm{H}_{2}$

$6.75 \mathrm{E}+05$

2.4

207.0

2701. $\mathrm{C}_{6} \mathrm{H}_{7}-13-5 \mathrm{M}+\mathrm{CH}_{3}=\mathrm{S} 6 \mathrm{XMCH} 13 \mathrm{E}+\mathrm{CH}_{4}$

$7.38 \mathrm{E}+00$

3.3

4002.0

2702. $\mathrm{C}_{6} \mathrm{H}_{7}-13-5 \mathrm{M}+\mathrm{O}=\mathrm{S} 6 \mathrm{XMCH} 13 \mathrm{E}+\mathrm{OH}$

$1.32 \mathrm{E}+06$

2.4

1210.0

$5.53 \mathrm{E}+04$

2.6

$-1919.0$

2704. $\mathrm{S} 6 \mathrm{XMCH} 13 \mathrm{E}=\mathrm{A} 1+\mathrm{CH}_{3}$

$4.24 \mathrm{E}+21$

$-3.9$

22867.0

2705. $\mathrm{S} 6 \mathrm{XMCH} 13 \mathrm{E}=\mathrm{A}_{1} \mathrm{CH}_{3}+\mathrm{H}$

$2.06 \mathrm{E}+20$

$-3.8$

23117.0

The geometry and the energy of the reactants, products, and transient states were calculated by using CBS-QB3 method. The rate constants from 500 to $1500 \mathrm{~K}$ (interval by $100 \mathrm{~K}$ ) of each reaction were calculated by using the ChemRate software, "biomolecular reaction" option. The coefficients (A, n, and Ea) were the numerical fitting results by using the Arrhennius Law $\left(k=A \cdot T^{n}\right.$. $\exp \left(-\frac{E_{a}}{R T}\right)$, where $R=\frac{4185.9}{8.314}=503.5$ when the unit of $\mathrm{E}_{\mathrm{a}}$ is $\left.c a l\right)$. 
Section 3: Calculated results of $\mathrm{H}-\mathrm{abstraction}$ reactions of $\mathrm{T} 135 \mathrm{MCH}$
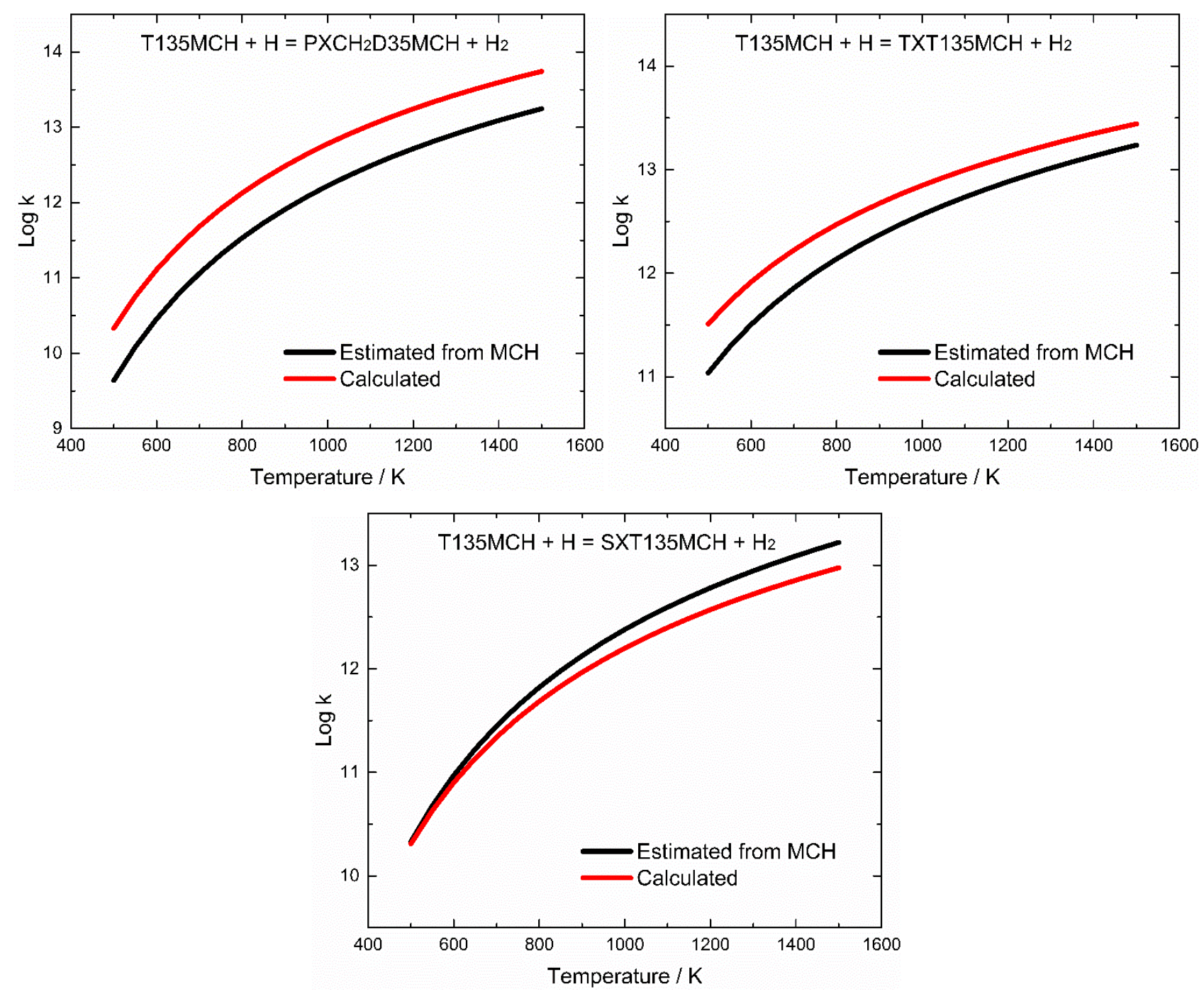

Fig S1 The comparison between the estimated rate constants from methylcyclohexane and the calculated results.

The geometry and the energy of the reactants, products, and transient states were calculated by using CBS-QB3 method. The rate constants from 500 to $1500 \mathrm{~K}$ (interval by $100 \mathrm{~K}$ ) of each reaction were calculated by using the ChemRate software, "biomolecular reaction" option. The coefficients (A, n, and Ea) were the numerical fitting results by using the Arrhenius Law $\left(k=A \cdot T^{n} \cdot \exp \left(-\frac{E_{a}}{R T}\right)\right.$, where $R=\frac{4185.9}{8.314}=503.5$, with $\mathrm{E}_{\mathrm{a}}$ given in $\left.c a l\right)$. 
Section 4: Thermochemical data of T135MCH and its derived species

Table S3 Names, structures, and thermochemical data of T135MCH and its derived species

\begin{tabular}{|c|c|c|c|c|c|c|c|c|c|c|c|}
\hline \multirow{2}{*}{ Species } & \multirow{2}{*}{ Structure } & \multirow{2}{*}{$\Delta H_{f, 298 \mathrm{~K}}^{\circ}(\mathrm{kcal} / \mathrm{mol})$} & \multirow{2}{*}{$S_{298 K}^{\circ}(\mathrm{cal} / \mathrm{mol} / \mathrm{K}$} & \multicolumn{8}{|c|}{$C_{p}^{\circ}(T)(\mathrm{cal} / \mathrm{mol} / \mathrm{K})$} \\
\hline & & & & 298 & 400 & 500 & 600 & 800 & 1000 & 1500 & 2000 \\
\hline $\mathrm{T} 135 \mathrm{MCH}$ & & -48.06 & 90.95 & 42.96 & 58.49 & 71.71 & 83.11 & 101.08 & 113.83 & 133.10 & 142.93 \\
\hline PXCH2D35MCH & & 46.70 & 96.62 & 42.90 & 57.97 & 70.57 & 81.31 & 98.17 & 110.18 & 125.63 & 138.45 \\
\hline TXT135MCH & & -15.53 & 96.24 & 42.59 & 57.44 & 69.96 & 80.70 & 97.67 & 109.80 & 125.43 & 138.34 \\
\hline CH3SXD35MCH & & -15.53 & 95.78 & 42.64 & 57.62 & 70.29 & 81.17 & 98.27 & 110.38 & 127.56 & 138.74 \\
\hline $\mathrm{CH} 2 \mathrm{D} 35 \mathrm{MCH}$ & & -20.41 & 94.08 & 39.91 & 55.02 & 67.72 & 78.50 & 95.10 & 106.47 & 124.64 & 132.89 \\
\hline
\end{tabular}




\begin{tabular}{|c|c|c|c|c|c|c|c|c|c|c|}
\hline T135MCHE & -21.46 & 96.94 & 43.83 & 58.23 & 70.24 & 80.36 & 95.78 & 106.28 & 124.34 & 132.60 \\
\hline C5H7-13-2M & 10.26 & 83.90 & 30.49 & 38.20 & 44.68 & 50.19 & 58.75 & 64.77 & 74.97 & 80.92 \\
\hline $\mathrm{C} 5 \mathrm{H} 7-13-2 \mathrm{CH} 2$ & 42.36 & 82.39 & 29.55 & 37.02 & 43.21 & 48.43 & 56.43 & 61.99 & 70.12 & 77.27 \\
\hline $\mathrm{CH} 2 \mathrm{~S} 2 \mathrm{XD} 35 \mathrm{MCH}$ & 4.40 & 95.28 & 39.35 & 53.83 & 65.96 & 76.24 & 92.04 & 102.86 & 118.54 & 128.68 \\
\hline T3XT135MCH1E & 3.35 & 97.23 & 43.23 & 56.86 & 68.15 & 77.63 & 92.13 & 102.08 & 116.61 & 127.97 \\
\hline S6XT135MCH1E & -1.55 & 90.95 & 42.96 & 58.49 & 71.71 & 83.11 & 101.08 & 113.83 & 133.10 & 142.93 \\
\hline $\mathrm{CH} 2 \mathrm{D} 35 \mathrm{MCH} 2 \mathrm{E}$ & 2.68 & 92.19 & 40.08 & 54.07 & 65.48 & 74.86 & 88.54 & 97.30 & 113.25 & 120.89 \\
\hline
\end{tabular}




\begin{tabular}{|c|c|c|c|c|c|c|c|c|c|c|}
\hline T135MCH13E & 3.26 & 94.85 & 46.73 & 59.19 & 69.47 & 78.02 & 90.78 & 99.26 & 114.60 & 121.80 \\
\hline $\mathrm{S} 4 \mathrm{XCH} 2 \mathrm{D} 35 \mathrm{MCH} 2 \mathrm{E}$ & 27.48 & 93.39 & 39.53 & 52.87 & 63.71 & 72.59 & 85.49 & 93.67 & 108.19 & 116.57 \\
\hline S6XCH2D35MCH2E & 27.48 & 93.39 & 39.53 & 52.87 & 63.71 & 72.59 & 85.49 & 93.67 & 108.19 & 116.57 \\
\hline Т5ХT135MCH13E & 28.07 & 95.13 & 46.13 & 57.83 & 67.38 & 75.29 & 87.13 & 95.06 & 106.37 & 117.11 \\
\hline S6XT135MCH13E & 28.07 & 89.88 & 44.48 & 56.35 & 65.91 & 75.75 & 87.73 & 95.63 & 108.95 & 117.51 \\
\hline $\mathrm{CH} 2 \mathrm{D} 35 \mathrm{MCH} 24 \mathrm{E}$ & 27.93 & 89.88 & 44.48 & 56.35 & 65.91 & 73.65 & 84.66 & 91.46 & 104.69 & 111.00 \\
\hline
\end{tabular}




\begin{tabular}{|c|c|c|c|c|c|c|c|c|c|c|}
\hline CH2D35MCH25E & 21.20 & 91.94 & 44.40 & 56.32 & 65.90 & 73.66 & 84.67 & 91.45 & 104.52 & 110.98 \\
\hline D35MCHE & -13.23 & 88.76 & 38.39 & 51.08 & 61.70 & 70.69 & 84.50 & 93.99 & 109.47 & 116.94 \\
\hline S4XD35MCH1E & 33.27 & 90.02 & 38.07 & 50.21 & 60.28 & 68.75 & 81.69 & 90.55 & 103.44 & 112.78 \\
\hline C6H7-13-5M & 6.71 & 93.17 & 37.15 & 46.99 & 55.17 & 62.04 & 72.52 & 79.71 & 91.74 & 98.79 \\
\hline S6XMCH13E & 36.30 & 87.86 & 40.74 & 50.84 & 59.16 & 66.09 & 76.45 & 83.34 & 94.48 & 101.88 \\
\hline S7XC7H11-1-46M & 20.52 & 117.91 & 47.57 & 60.46 & 71.21 & 80.37 & 94.81 & 105.30 & 119.39 & 132.93 \\
\hline S6XC7H11-1-24M & 17.34 & 118.80 & 47.47 & 60.27 & 70.94 & 80.01 & 94.28 & 104.63 & 119.82 & 132.61 \\
\hline S7XC7H11-2-46M & 17.71 & 118.08 & 49.92 & 62.55 & 73.14 & 82.22 & 96.70 & 107.36 & 121.43 & 134.92 \\
\hline S5XC5H8-1-4M & 36.42 & 91.73 & 31.29 & 39.58 & 46.43 & 52.23 & 61.40 & 68.15 & 75.63 & 86.12 \\
\hline
\end{tabular}




\begin{tabular}{|c|c|c|c|c|c|c|c|c|c|c|}
\hline S4XC5H8-1-2M & 33.24 & 92.62 & 31.19 & 39.38 & 46.15 & 51.87 & 60.87 & 67.47 & 76.57 & 85.80 \\
\hline S5XC5H8-2-4M & 33.61 & 91.90 & 33.64 & 41.66 & 48.35 & 54.08 & 63.29 & 70.20 & 77.99 & 88.13 \\
\hline $\mathrm{CH} 2 \mathrm{qj}$ D35MCH & -32.55 & 110.83 & 48.84 & 64.96 & 78.47 & 89.93 & 107.65 & 119.96 & 138.27 & 149.95 \\
\hline $\mathrm{CH} 2 \mathrm{q} 2 \mathrm{jD} 35 \mathrm{MCH}$ & -21.15 & 116.55 & 50.26 & 65.99 & 79.15 & 90.32 & 107.63 & 119.67 & 137.66 & 149.28 \\
\hline DMCHo-P2 & -71.41 & 43.13 & 51.65 & 65.64 & 77.50 & 87.60 & 102.91 & 112.40 & 116.26 & 119.74 \\
\hline $\mathrm{CHOD} 35 \mathrm{MCH} 2 \mathrm{j}$ & -20.31 & 103.48 & 41.70 & 56.44 & 68.92 & 79.62 & 96.23 & 107.36 & 117.65 & 125.54 \\
\hline
\end{tabular}




\begin{tabular}{|c|c|c|c|c|c|c|c|c|c|}
\hline CHOD35MCH1E & 104.46 & 45.18 & 60.21 & 72.79 & 83.47 & 99.98 & 111.55 & 130.03 & 137.40 \\
\hline CHOD35MCH2E & & & & & & & & & \\
\hline
\end{tabular}




\begin{tabular}{|c|c|c|c|c|c|c|c|c|c|c|}
\hline $\mathrm{CHCHCHO}$ & -15.66 & 67.78 & 16.22 & 19.98 & 23.20 & 25.96 & 30.27 & 33.33 & 37.73 & 39.82 \\
\hline $\mathrm{S} 5 \mathrm{X} 2 \mathrm{C} 5 \mathrm{H} 9$ & 41.13 & 83.41 & 25.79 & 32.24 & 37.59 & 42.16 & 49.56 & 55.16 & 63.43 & 69.49 \\
\hline CHOD35MCH1E4j & 1.75 & 105.73 & 44.86 & 59.33 & 71.37 & 81.54 & 97.17 & 108.11 & 126.00 & 134.39 \\
\hline CHOD35MCH13E & 1.75 & 105.73 & 44.86 & 59.33 & 71.37 & 81.54 & 97.17 & 108.11 & 126.00 & 134.39 \\
\hline TMCH2qj & -37.60 & 108.33 & 49.58 & 65.56 & 79.13 & 90.76 & 108.66 & 120.23 & 127.15 & 133.08 \\
\hline TMCH2q4j & -26.20 & 114.05 & 51.03 & 66.59 & 79.81 & 91.14 & 108.63 & 119.94 & 126.53 & 132.22 \\
\hline ТМCHo-24 & -26.20 & 114.05 & 51.03 & 66.59 & 79.81 & 91.14 & 108.63 & 119.94 & 126.53 & 132.22 \\
\hline
\end{tabular}




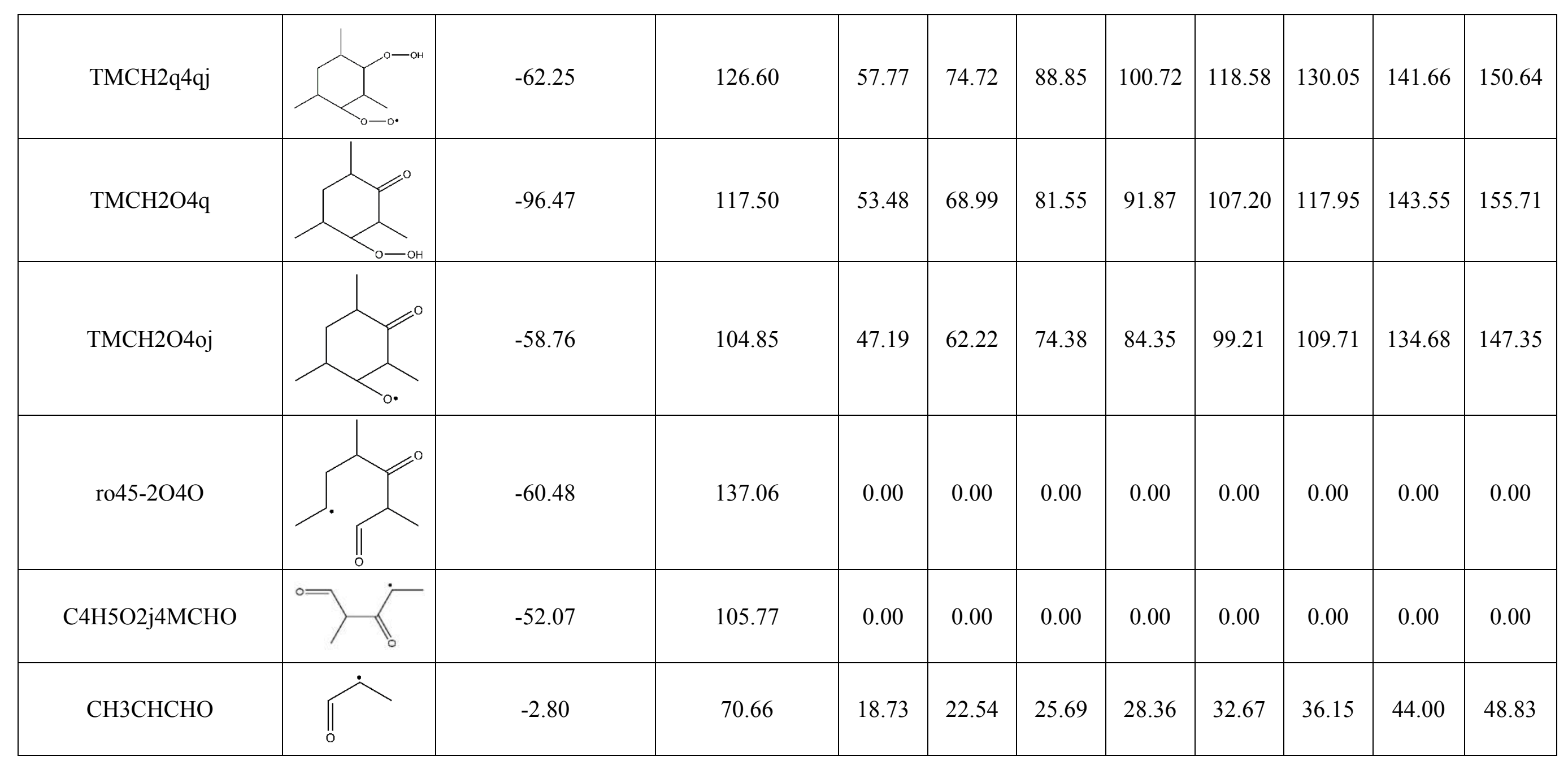




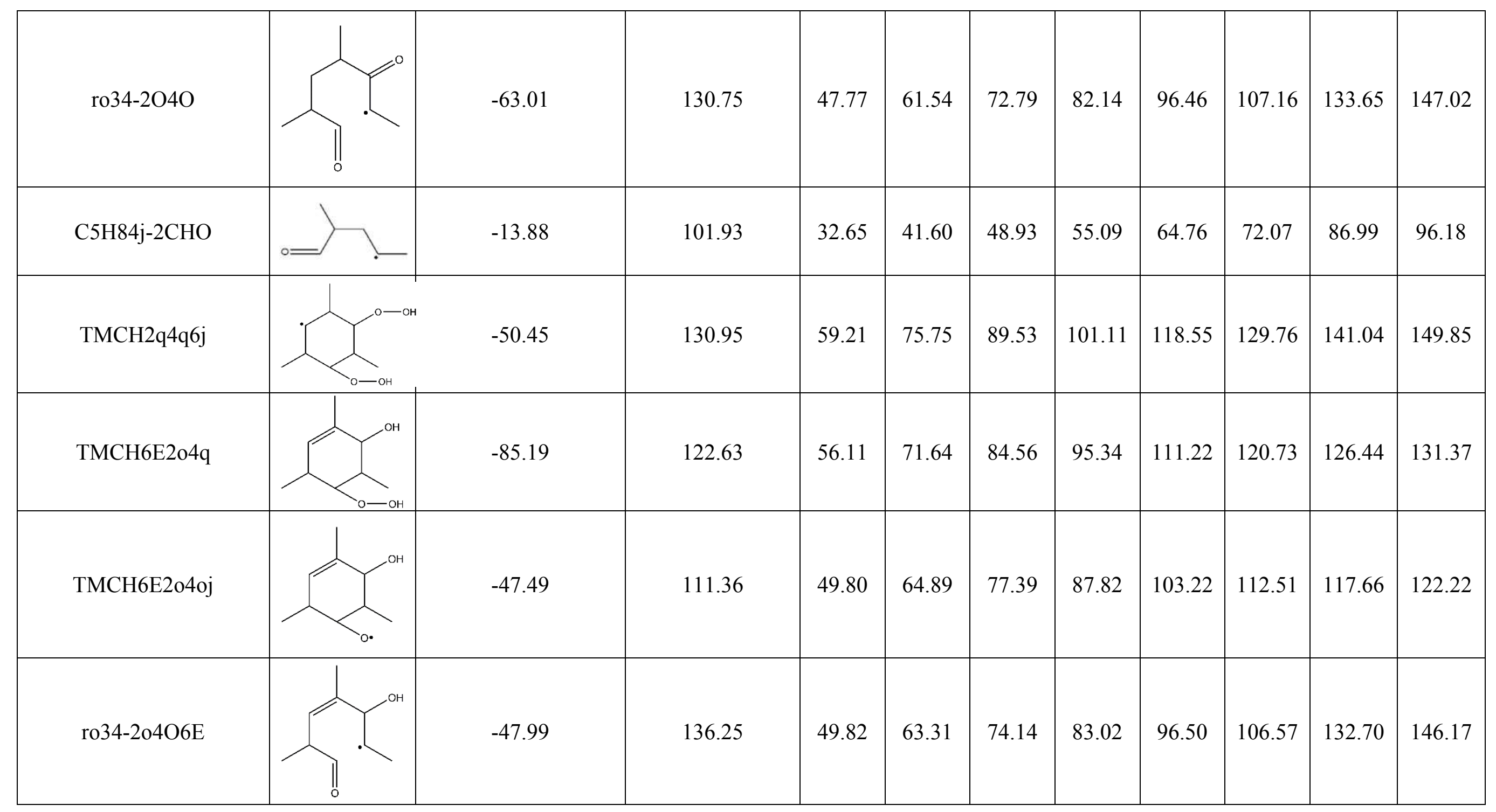




\begin{tabular}{|c|c|c|c|c|c|c|c|c|c|c|}
\hline $\mathrm{S} 2 \mathrm{X} 2 \mathrm{C} 5 \mathrm{H} 8-4 \mathrm{CHO}$ & -15.66 & 67.78 & 16.22 & 19.98 & 23.20 & 25.96 & 30.27 & 33.33 & 37.73 & 39.82 \\
\hline $\mathrm{aC} 3 \mathrm{H} 5 \mathrm{OH}$ & -37.28 & 78.93 & 19.19 & 22.69 & 25.90 & 28.88 & 34.14 & 38.44 & 44.80 & 48.88 \\
\hline ТMCH2O4j & -25.22 & 100.51 & 44.95 & 58.98 & 70.44 & 79.96 & 94.40 & 104.72 & 127.45 & 139.67 \\
\hline TMCH3E2O & -46.99 & 104.17 & 44.07 & 58.92 & 70.91 & 80.71 & 95.19 & 105.48 & 131.13 & 139.72 \\
\hline TMCH4E2O & -51.74 & 104.18 & 38.00 & 53.17 & 65.39 & 75.38 & 90.15 & 100.68 & 127.61 & 137.78 \\
\hline TMCH3E2O5j & -22.18 & 105.83 & 43.47 & 57.55 & 68.82 & 77.98 & 91.54 & 101.28 & 126.91 & 137.01 \\
\hline TMCH35E2O & -22.18 & 105.83 & 43.47 & 57.55 & 68.82 & 77.98 & 91.54 & 101.28 & 126.91 & 137.01 \\
\hline
\end{tabular}




\begin{tabular}{|c|c|c|c|c|c|c|c|c|c|c|}
\hline ro61-2O3E5E & 6.22 & 115.07 & 48.59 & 60.86 & 70.46 & 78.12 & 89.41 & 98.32 & 129.63 & 140.02 \\
\hline C5H64j-13-2M & -13.88 & 101.93 & 32.65 & 41.60 & 48.93 & 55.09 & 64.78 & 72.07 & 86.99 & 96.18 \\
\hline ro23-2O3E & -14.64 & 125.15 & 48.01 & 60.28 & 70.65 & 79.56 & 93.67 & 103.83 & 119.39 & 129.95 \\
\hline ro56-2O4E & -12.57 & 125.32 & 44.21 & 57.36 & 68.17 & 77.25 & 91.35 & 101.60 & 120.45 & 132.26 \\
\hline S6X2C7H12-4M & 22.76 & 110.78 & 44.37 & 55.20 & 64.32 & 72.19 & 84.89 & 94.40 & 109.01 & 118.97 \\
\hline C5H9-2-4COj & -2.70 & 98.59 & 29.56 & 37.04 & 43.43 & 48.97 & 57.86 & 64.26 & 72.60 & 78.87 \\
\hline $\mathrm{S} 4 \mathrm{X} 2 \mathrm{C} 5 \mathrm{H} 9$ & 23.70 & 79.98 & 23.33 & 30.02 & 35.84 & 40.96 & 49.21 & 55.26 & 64.72 & 71.28 \\
\hline
\end{tabular}


Section 5: Further mol fraction profiles of surrogate oxidation and the selection of JSR experimental condition.
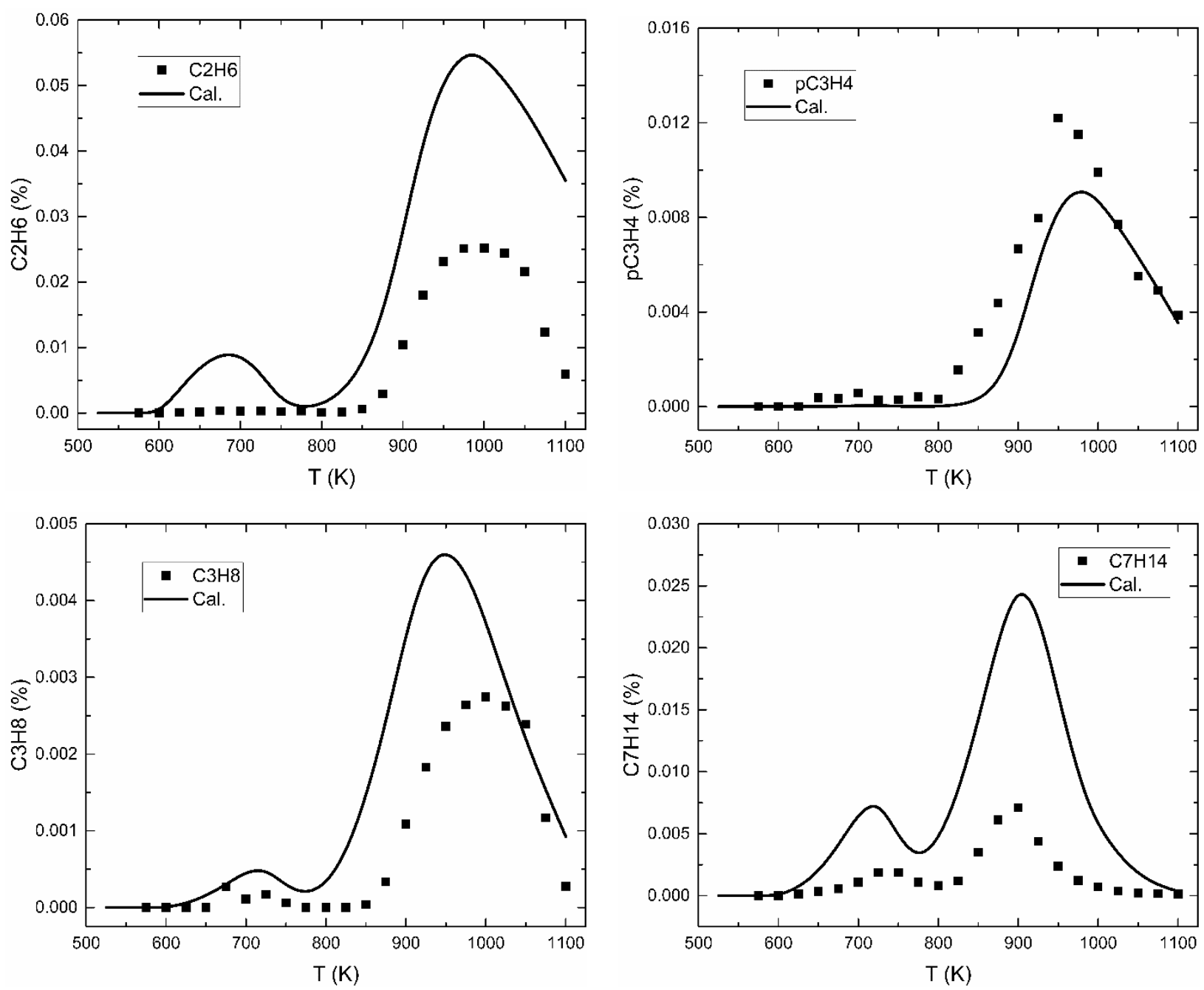

Fig. S2 Mol fraction profiles of surrogate oxidation.

It is well known from literature and from our own experience that experiments performed at fuel rich conditions such as $\varphi=2.0$ will favor the formation of aromatic species considerably. Experiments performed at $\varphi=2.0$ will generate more and different types of intermediates with a higher concentration. This is of advantage for two major reasons: (i) species can be easier detected by GC and GC-MS; and (ii) the information on the intermediates pattern is of benefit for the validation and improvement of the mechanism. In contrast, the oxidation of any fuel at equivalence ratios of $\varphi=1.0$ and/or $\varphi=0.4$ would generate less intermediates with less concentration and/or rapid generation and consumption. For these reasons, we decided to perform the experiments of a very fuel-rich mixture, at an equivalence ratio of $\varphi=2.0$ 
Section 6: Comparison of the simulated results by using Banerjee's and Mzé-Ahmed's n-dodecane model.
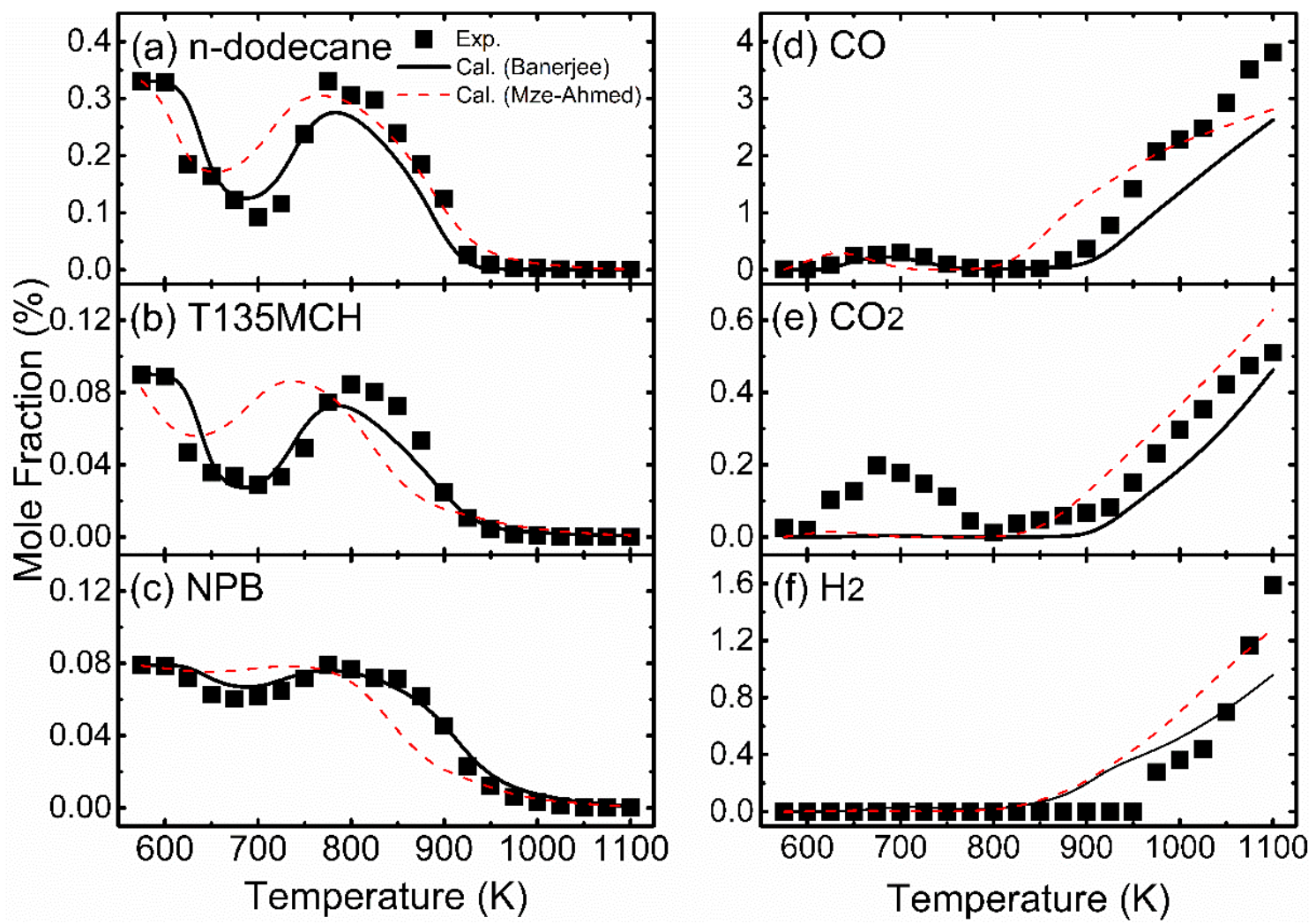

Fig. S3 The mole fraction profiles of major species, simulated by two different surrogate models (differed by n-dodecane sub-mech): black solid line - Banerjee's n-dodecane sub-mech; red dash line - Mzé-Ahmed's n-dodecane sub-mech.

Banerjee's model is able to match the NTC region much better. Using Mzé-Ahmed's model, a stronger NTC region was predicted than by using Banerjee's model. Figure S3 shows the simulated results by using Mzé-Ahmed's n-dodecane sub-mechanism, in our surrogate model, instead of Banerjee's n-dodecane sub-mechanism. Under this assumption, the predictions reveal a minor agreement with the experimental data.

Furthermore, the Mzé-Ahmed's low-temperature mechanism of n-dodecane is too comprehensive for a surrogate mechanism, as our mechanism need to be validated against ignition delay and flame speed simulations.

The equivalence ratio, as chosen within the present work, $\varphi=2.0$ means less oxygen and is thus closer to the condition of a pyrolysis, with decomposition reactions playing a more important role 
within the consumption of the fuel considered and with a minor influence of peroxy and hydroperoxy radicals, besides $\mathrm{HO}_{2}$.

\section{References}

[1] J.T. Scanion, D.E. Willis, Calculation of flame ionization detector relative response factors using the effective carbon number concept, J. Chromatogr. Sci. 23 (1985) 333-340.

[2] American Society for Testing and Material, ASTM D7504-2012, Standard test method for trace impurities in monocyclic aromatic hydrocarbon by gas chromatography and effective carbon number, West Conshohocken, ASTM International, 2012. 